2

\title{
A Remote Sensing Contribution to Flood Modelling in an Inaccessible Mountainous River Basin
}

\author{
Alamgeer Hussain ${ }^{1}$, Jay Sagin ${ }^{2 *}$, Kwok P. Chun ${ }^{3}$ \\ ${ }^{1}$ Secretariat of Agriculture, Livestock and Fisheries Department, Gilgit Baltistan, Pakistan \\ ${ }^{2}$ Nazarbayev University, 53 Kabanbay Batyr Avenue, Astana, 010000, Kazakhstan \\ ${ }^{3}$ Hong Kong Baptist University, Baptist University Rd, Kowloon Tong, Hong Kong \\ * Correspondence: zhanay.sagintayev@nu.edu.kz; WhatsApp: +7-702-557-2038, +1-269-359-5211
}

\begin{abstract}
Flash flooding, a hazard which is triggered by heavy rainfall is a major concern in many regions of the world often with devastating results in mountainous elevated regions. We adapted remote sensing modelling methods to analyse one flood in July 2015, and believe the process can be applicable to other regions in the world. The isolated thunderstorm rainfall occurred in the Chitral River Basin (CRB), which is fed by melting glaciers and snow from the highly elevated Hindu Kush Mountains (Tirick Mir peak's elevation is $7708 \mathrm{~m}$ ). The devastating cascade, or domino effect, resulted in a flash flood which destroyed many houses, roads, and bridges and washed out agricultural land. CRB had experienced devastating flood events in the past, but there was no hydraulic modelling and mapping zones available for the entire CRB region. That is why modelling analyses and predictions are important for disaster mitigation activities. For this flash flood event, we developed an integrated methodology for a regional scale flood model that integrates the Tropical Rainfall Measuring Mission (TRMM) satellite, Geographic Information System (GIS), hydrological (HEC-HMS) and hydraulic (HEC-RAS) modelling tools. We collected and use driver discharge and flood depth observation data for five river sub-stream areas, which were acquired in cooperation with the Aga Khan Rural Support Program (AKRSP) organization. This data was used for the model's calibration and verification. This modelling methodology is applicable for other regional studies especially for rough mountainous areas which lack local observations and river discharge gauges. The results of flood modelling are useful for the development of a regional early flood warning system and flood mitigation in hazardous flood risk areas. The flood simulations and prepared connected video visualization can be used for local communities. This approach is applicable for flood mitigation strategies in other regions.
\end{abstract}

Keywords: TRMM; HEC-HMS; HEC-RAS;GIS; Hydrological Model; Hydraulic Model; Flood; Chitral River Basin

\section{Introduction}

Flash floods, which are triggered by heavy rainfall, are a major hazard in many regions in the world. In mountainous regions [1-3], devastating results include fatalities, property and agricultural land damage [4]. The CRB is one hazardous area where flood intensity has been increasing over the last two decades. Two recent devastating floods in this district occurred in 2010 and 2015 .During the 2015 flood, a total of 1,486 houses were damaged and 307,500 people were displaced. Furthermore, 30 schools, 10 powerhouses, 13 bridges, 154 water supply schemes, and 81 irrigation channels were badly damaged and 3,225 acres of standing crops were washed away [5]. According to the National Disaster Management Authority (NDMA) and Pakistan Meteorological Department (PMD) annual 
reports, each year more deaths and damage occur due to flooding in the Chitral district than any other weather related hazard. Climate change has resulted in increased melting of glaciers and snow coupled with thunderous rainstorms. The lack of information about flood zones and their risks can lead government officials to be unable to create awareness and preparedness in the community about future floods [6, 7]. The major cause of hydraulic floods is a combination of torrential rain and Glacial Lake Outburst Floods (GLOF), a situation worsened by pre-existing factors such as deforestation and excessive grazing that have contributed to mud slides in already economically compromised communities [8-11]. The unavailability of automatic weather stations and river gauges within the CRB justify the development and calibration of a flood prediction model for extreme weather events. The CRB consists of rough mountains and narrow valleys which also hinder field measurement and the development of probabilistic flood maps.

Unprecedented extreme weather, due to the increase of the average global temperature in recent years, has induced floods and demonstrated the necessity of reliable flood models for advanced early warning systems for extreme weather situations [12]. We developed a methodology that integrates free available remote sensing data, including Tropical Rain Measurement Mission (TRMM) satellite precipitation data, Digital Elevation Model (DEM), Geographic Informational System (GIS), Hydrological model (Hydrologic Engineering Centre's Hydraulic Modelling System: HEC-HMS) and Hydraulic model (Hydrologic Engineering Centre's River Analysis System: HEC-RAS)which was developed by the US Army Corps of Engineers[13-17].However, there are some limitations in accuracy due to course resolution of the precipitation and DEM data [18, 19].

The TRMM, a joint US-Japan satellite mission, was launched in 1997 to monitor tropical and subtropical precipitation and to estimate its associated latent heating covering the latitude band of 50N-50S.The TRMM generated a global estimation of precipitation based on remote sensing observation. The TRMM 3B42 algorithm, also known as Multi-Satellite Precipitation Analysis (TMPA), has high spatial (0.258) and temporal (3h) resolution, and is widely used in hydrological modelling, especially in data sparse regions [20-22]. In this study we used TRMM 3B42 precipitation data for July 16 and 17, 2015. This data product consists of TRMM TMPA Rainfall, which merges satellite rainfall estimates (S) with gauge data (G). TRMM Microwave Imager precipitation (TMI; TRMM product 2A12) was calibrated through the microwave precipitation from multiple low-earth-orbiting satellites and then calibrated to the TRMM Combined Instrument precipitation (TCI; TRMM product 2B31) based on 3B42 algorithm. These are merged to produce a microwave-only best estimate every 3 hours. The infrared precipitation estimates (from multiple geosynchronous satellites) are then calibrated to the microwave estimate and used to fill in the regional gaps in the merged microwave field to produce a combined satellite rainfall estimate every 3 hours. These 3-hourly combined satellite estimates are then summed to the monthly scale and recalibrated with a monthly precipitation gauge analysis to provide the final SG-merged precipitation estimate and become a Level 3 (L3) 3 hourly $0.25^{\circ} \times 0.25^{\circ}$ quasi-global $\left(50^{\circ} \mathrm{N}-\mathrm{S}\right)$ gridded SG-rainfall database [23-25].Currently, remote sensing based precipitation data such as TRMM is afavourable alternative to the conventional precipitation observations using rainfall gauges. TRMM data provide real time distributed data which have improved research results in the field of hydrological modelling [26-28].

Hydrological modelling is a commonly used tool to estimate a basin's hydrological response to precipitation. The selection of the model depends on the basin and the objective of the hydrological prediction in the basin. The HEC-HMS is a reliable model developed by the US Army Corps of Engineers that could be used for many hydrological simulations [29]. HEC-HMS is a rainfall-runoff model that converts precipitation excess to overland flow and channel runoff. The River Analysis system (HEC-RAS) is a hydraulic model that models the unsteady flow through the river channel network based on the HEC-HMS-derived hydrographs [30]. HEC-RAS is an integrated system of software, designed for interactive use in a multi-tasking environment. The system is comprised of a graphical user interface (GUI).With separate analysis components, data storage, management capabilities, graphics and reporting facilities the HEC-RAS system contains one and two dimensional river analysis components for: (1) Steady flow water surface profile computations, (2) Unsteady flow 
simulations, (3) movable boundary sediment transport computations, and (4) water quality analysis. A key element is that all four components use a common geometric data representation and common geometric and hydraulic computation routines [31]. This integrated flood inundation mapping approach is useful and accurate for inaccessible mountainous areas that lack river gauges and automatic weather stations.

\section{Materials and Methods}

\subsection{Study Area}

The research area of CRB (also known as Kunar River Basin (KRB)), is an upper sub-basin of the Kabul River basin located in north western Pakistan, and is the second largest river of Pakistan. It has five sub basins namely Mastuj, Laspur, Mulkhow, Lotkhow and Chitral (see Figure1). Chitral area is located at the epicentre of the region that hosts some of Pakistan's highest Hindu Kush Mountains (Tirick Mir peak elevation $7708 \mathrm{~m}$ ) and is subjected to glacial melting due to global warming [32, 33]. The people living in this mountainous region are exposed to extreme climatic events including flash floods, avalanches, glacier breaks, GLOFs, and landslides. These disasters ultimately affect human lives, meagre livelihoods, resources and scarcely available infrastructure [34]. The mean temperature in Chitral has been increasing, resulting in unprecedented precipitation, and leading to disastrous floods [35]. The drainage of CRB is about $11400 \mathrm{~km}^{2}$ (see Figure 1).

Figure1: Map of sub basins of CRB. The base map shows the DEM.

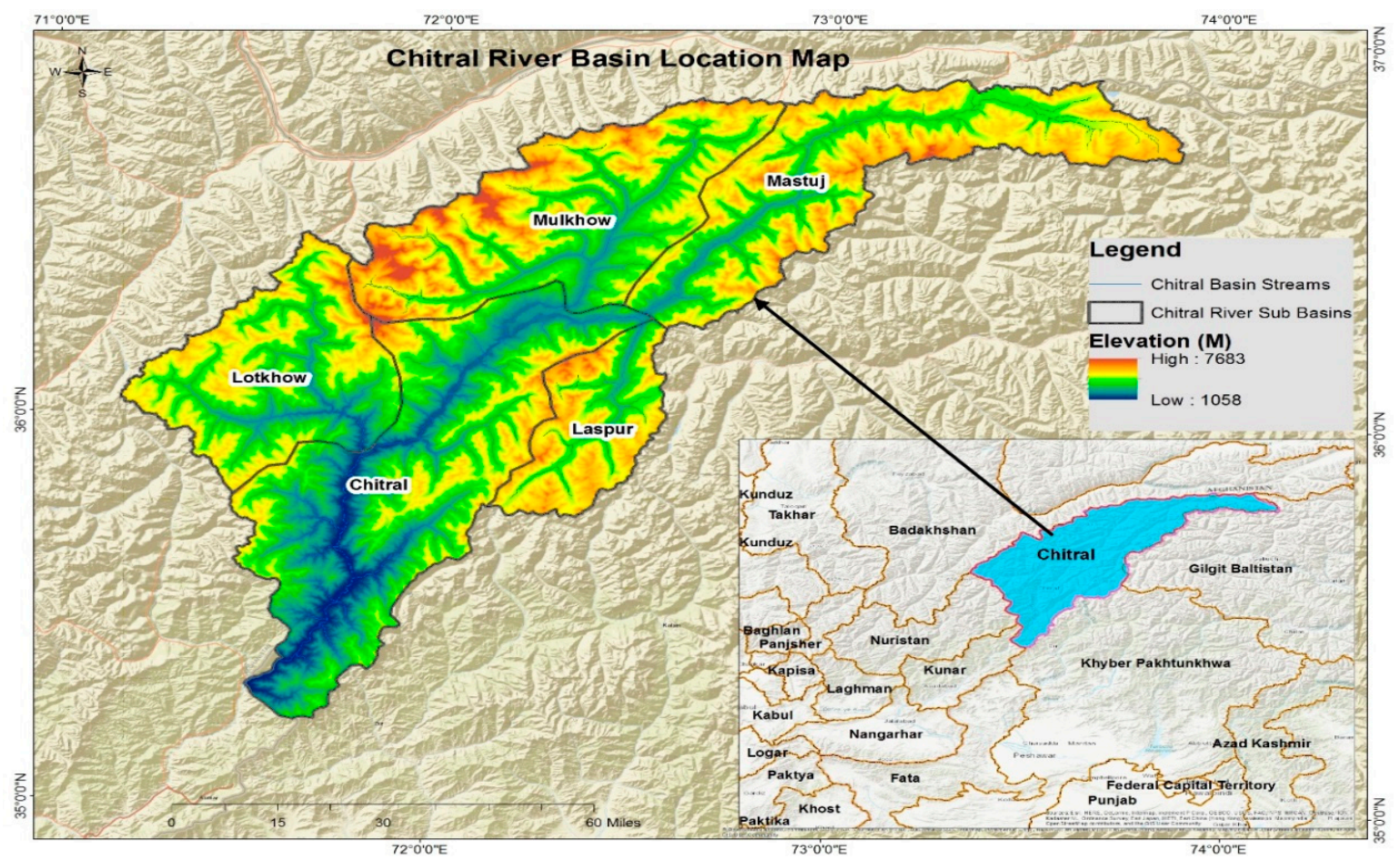

The Chitral River is snow and glacier fed and the mean annual runoff of the river for 34 years (1964-67, 1969-98) has been $8670 \mathrm{Mm}^{3}$ with the maximum discharge recorded at $1585 \mathrm{~m}^{3} / \mathrm{s}$ on July 16 , 1973 and the minimum discharge recorded at $46 \mathrm{~m}^{3} / \mathrm{s}$ on March 10, 1964[36, 37]. The source of the Chitral River is Chiantar Glacier Yarkhun valley and it flows until it enters Afghanistan. Throughout the route, it has various names. During its journey through the cast and long valley of Yarkhun, it is called the Yarkhun River [38]. At Mastuj, it is joined by Laspur River which is its first main tributary and drains a huge section of the northern face of the Shandur Hindu Raj range. From here it is called Mastuj River and continues until it reaches a place called Gankorini, four miles above Chitral town. Throughout its course the main stream collects numerous hill torrents and steams from both banks and the Torkhow River from the right. The Torkhow River drains the regions of Torkhow and Mulkhow watersheds. At Gankorini, it is joined by the Lotkoh River and from there on it becomes the 
128

129

130

131

132

133

134

135

136

137

138

139

140

141

142

143

144

145

146

147

148

149

150

151

152

153

154

155

156

157

158

159

160

161
Chitral River till it enters Afghanistan at Arandu. On its way, the Chitral River is joined by many streams and side valleys such as Jughoor Gole, AyunGole, Kalashgum, ShishiKuh and Ashuret. The main valley as a whole from Broghil to the border of Afghanistan is about 320 kilometres long. The average width of the valley is not more than 5/6 kilometres. The valley floor rises gradually from 3377 feet at Arandu to 12270 feet at Showar Shur in Broghil [39].

\subsection{Data Collection}

TRMM rainfall product 3B42 data for July 16 and 17, 2015 with three hour temporal resolution were downloaded from pmm.nasa.govwebsite in CDF format for CRB. The DEM for CRB was downloaded from USGS site and clipped for the research area of interest (AOI).Land use land cover (LULC) data for CRB was acquired from CCS Support Unit of IUCN-The World Conservation Union. LULC data was used to calculate the roughness values for the HEC-RAS and HEC-HMS modelling tools. Flood field observation discharge data for those two days were acquired in cooperation with AKRSP. This observation flood discharge data were used for the validation of simulated results through a comparison of flood stages. The geological and soil data were obtained from the Geological Survey of Pakistan (GSP).

\subsection{Flood Modelling Methodology}

The flood modelling methodology was developed through an integration of the remote sensing data TRMM, GIS for preparation of spatial data, HEC-HMS for measurement of rainfall-runoff and river analysis system (HEC-RAS) to delineate hydraulic modelling zones for CRB. This approach is useful for flood protective modelling in upstream areas and future development in downstream and low lying areas [40,41]. The DEM data was pre-processed using fill and sink tools in Arc GIS environment. The pre-processed DEM was used to generate the sub watershed boundary of CRB. A CRB boundary shape file was extracted through a watershed delineating process in Arc Map using a hydrology tool. TRMM rainfall data were downloaded in netCDF format, which is converted to raster layers using multidimensional tools. Next, netCDF Raster Layers in Arc GIS 10.2.2were made. The 3 hour rainfall interval TRMM data forJuly 16 and 17, 2015, were estimated by combining the netCDF raster and sub basins shape file using the zonal statistic tool in ArcGIS environment for five watersheds within the CRB: Yarkhun, Laspur, Mulkhow, Lotkhow and Kunar. The 3 hour rainfalls on July 16 and 17 were populated to cover the sub basins rainfall table in HEC-HMS environment for the calculation of rainfall-runoff (see Figure 2)[42, 23]. 

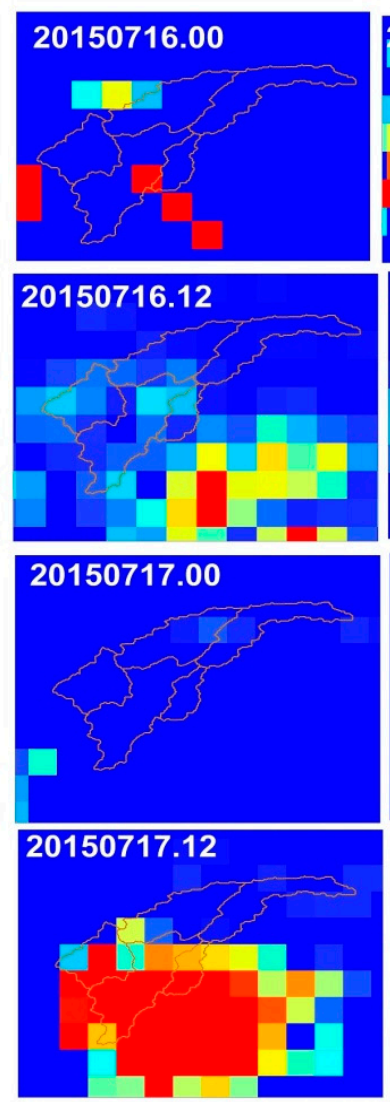
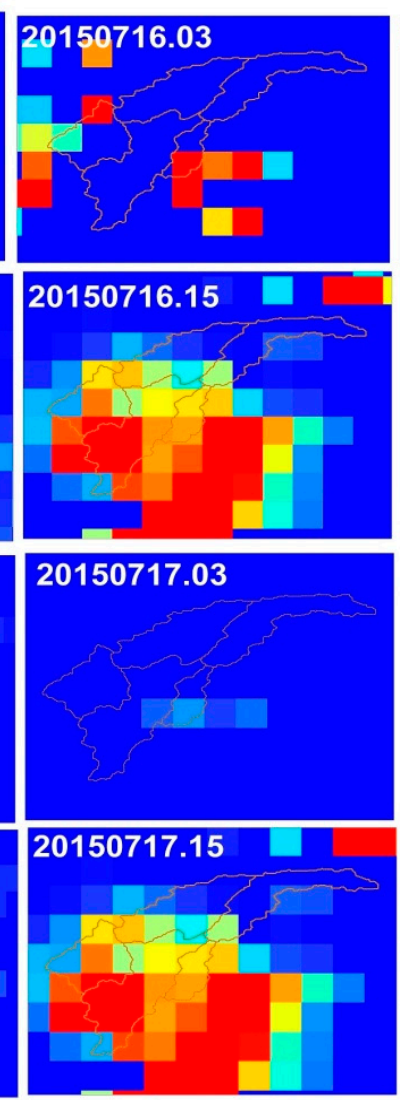
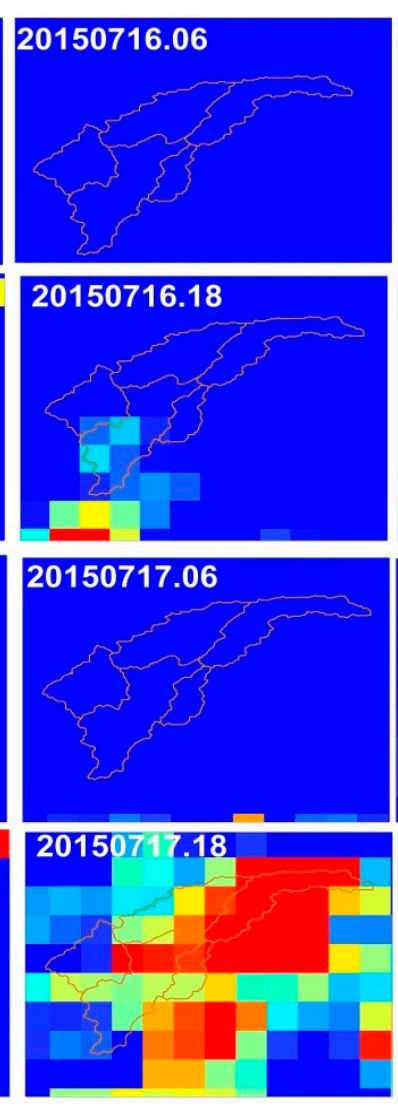

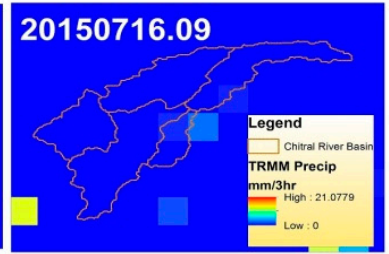

20150716.21

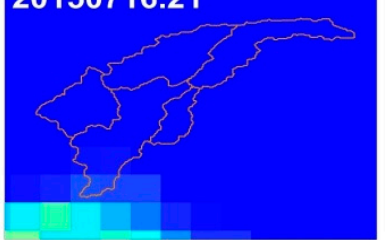

20150717.09

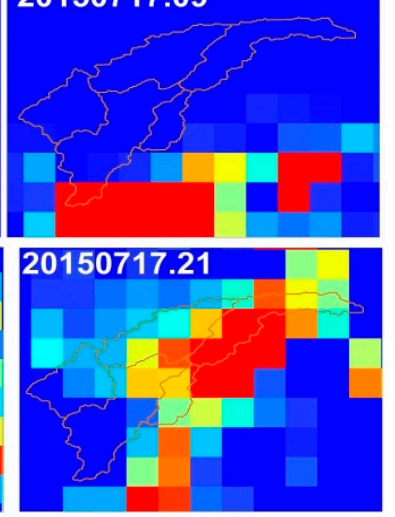

162

163

164

165

166

167

168

169

170

171

172

173

174

175

176

177

178

179

180

181

182

183

184

185

186

187

188

189

190

Figure2: Downloaded three hour TRMM based precipitation on July 16 and 17, 2015 in CRB.

HEC-HMS model was used to compute the rainfall-runoff for the five subbasins of the CRB. Watershed areas were prepared by using the basin model manager tool of HEC-HMS. A sub basin tool was used to create the five sub watersheds: Yarkhun, Laspur, Mulkhow, Lotkhow and Kunar. The junction tool was used to combine the streams. United States Department of Agriculture (USDA) Soil Conservation Service (SCS) Curve Number loss method was used for each sub basin of the CRB. The SCS method requires three input parameters: initial loss $(\mathrm{mm})$, constant rate $(\mathrm{mm} / \mathrm{h})$ and impervious area (\%). Next, SCS unit hydrograph and Clark unit hydrograph were applied to transform the method [44, 45]. Meteorological model, control specification and precipitation were populated in time series windows. These methods successfully simulated the main and sub stream flows within the CRB. The output of the model was the discharge hydrographs and time series flow table at each sub basin outlet. The simulated discharge data were validated with flood observation data from those two days. The flood observation data were collected in cooperation with AKRSP organization. The HEC-HMS output simulated discharge hydrographs and Time series flow data was used for flood inundation mapping in the HEC-RAS environment.

HEC-RAS modelling tool was used with input of the terrain areas, prepared geometrical data, unsteady flow data, and the execution output of flood inundation model. The flood inundation maps were imported to Arc Map for an overlay analysis to calculate the flood exposure, vulnerable road sites and bridge damage in the CRB [46]. RAS Mapper is a Geospatial tool (GIS) in HEC-RAS platform, and has been used for the geo projection and creation of terrain. RAS Mapper also has the capability to display the water surface elevations (traditional floodplain mapping), flood plain depths, flood plain boundaries and flow velocities [47].Geometric data for hydraulic flood modelling were prepared in the geometric window of HEC_RAS (5.0.0). Geometric data include the creation of mesh (2D flow area) for two dimensional modelling in HEC_RAS and boundary conditions (upstream and downstream). Terrain surface was used to create geometrical data in the geometric window of HEC-RAS. Computational mesh was created for 2D modelling in HEC-RAS. The mesh was generated with a computation point spacing of DX 300 and DY 300. The mesh contains 6115 cells. 
191

192

193

194

195

196

197

198

199

200

201

202

203

204

205

206

207

208

209

210

211

Mesh generates three parameters: maximum, minimum and average with area covered against each cell. There are 2993 maximum cells with area cover of674784.10 (sqft), minimum cells having 48880.36(sqft) area cover and average cell covering100955 (sqft) area. The manning values were set for the entire CRB which is mostly covered with barren land and Rocky Mountains. Four upstream locations were marked at the specific sites of Yarkhun, Laspur, Mulkhow, Lotkhow and one downstream area was marked at Osiak Drosh village [31]. The HEC-HMS based simulated discharge hydrographs and Time series flow data were populated in an unsteady flow data window of HEC-RAS for all five sub rivers basins of CRB and normal depth of downstream was set at 0.01[48]. Peak flood scenario was developed usingtwo dimensional unsteady flow routing (full Saint Venant equation, also called Diffusion wave equation). In the unsteady flow analysis, the model ran (geometry pre-processor, unsteady flow simulation) with simulation time (starting and ending) and computational setting (computational interval, hydrograph output interval, mapping output interval and detail output interval). Finally, unsteady flow analysis was executed, which generated flood depth, Velocity, and Water Surface Elevations (WSE). The results of the flood were visualized in RAS Mapper window and a flood simulation video was also developed in RAS mapper environment [49]. The results of flood surface, including the flood depth; velocity and WSE were exported from RAS mapper. These flood surfaces were imported in Arc Map to calculate the flood exposure, LULC flood exposure statistic, using flood surface polygon overlays and LULC shape files using intersection tool. The vulnerable roads and bridges along the CRB were also identified and measured using overlay analysis tools in ArcGIS environment [50]. The work flow diagram of the research study methodology is illustrated in Figure3.

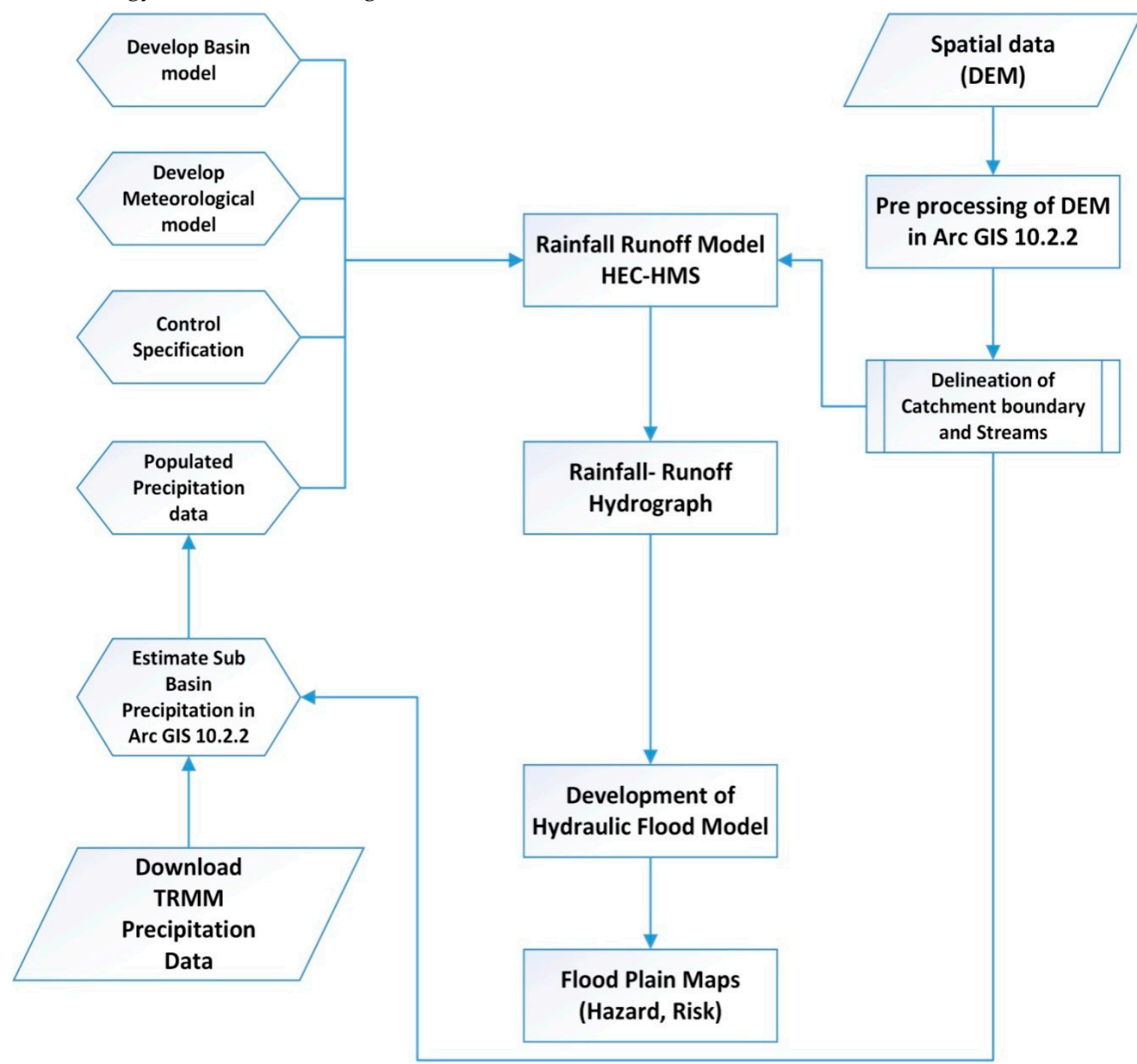


213

214

215

216

217

218

219

220

221

222

223

224

225

226

227

228

229

230

\section{Results}

The results of this study include the estimation of rainfall using TRMM satellite data from July 16 and 17, 2015, rainfall-runoff by integration of TRMM based rainfall data with other data in HEC-HMS environment, hydraulic flood inundation modelling through HEC-HMS based simulated discharge hydrographs, Time series runoff data in HEC-RAS, the development of flood depth, velocity maps and flood simulation video in RAS Mapper as well as an analysis of flood inundation, areas of risks flood exposure and flood hazard and risk maps development in Arc GIS environment [51].

\subsection{TRMM Rainfall data}

TRMM 3B42 precipitation data taken at 3 hour intervals were used to calculate the sub basin rainfall in Arc Map 10.2.2 by integrating multidimensional and zonal statistic tools for the five basin of the CRB. Two isolated thunder rainfalls occurred there on those days. A total of $29 \mathrm{~mm}$ of rain fell between 0900 and 2100 hours on July 16 while $38.1 \mathrm{~mm}$ of rain fell from 0900 to 2400 hours on July 17, 2015(see Figure 4). This isolated thunderstorm generated flash flooding which further damaged houses, washed out agricultural land and badly impacted the road infrastructure and power stations. The rainfall data was used in HEC-HMS environment to generate rainfall-runoff for each sub basin of CRB: Chitral/Kunar received 41.19mm, Lotkhow 17.97mm, Mulkhow5.36mm,Laspur 4.57 and Mastuj $1.88 \mathrm{~mm}$ (see Figure 5).

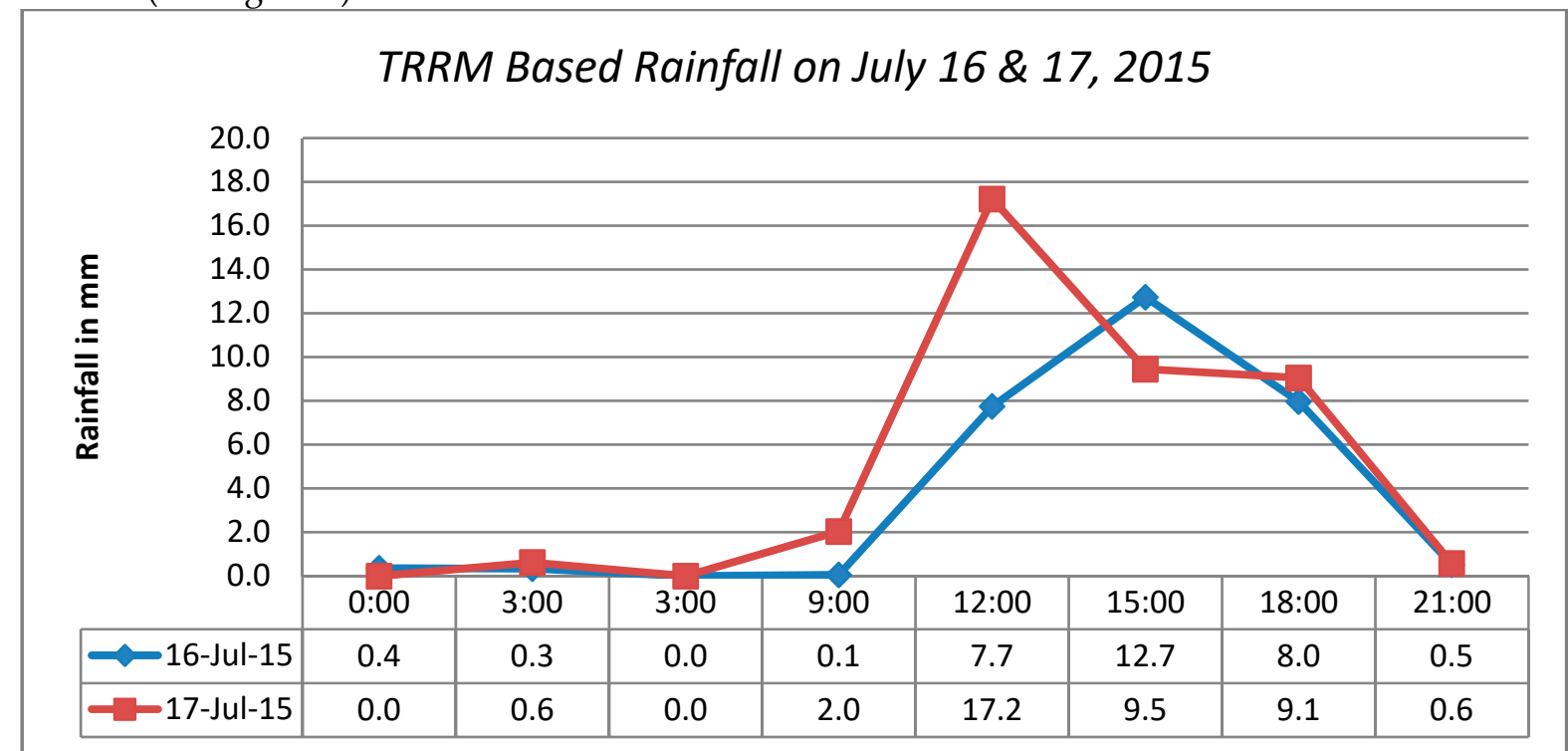

Figure4: Distribution of TRMM based rainfall recorded in 3 hour intervals in CRB.

\section{Rainfall distribution in Subbasins of Chitral Watershed}

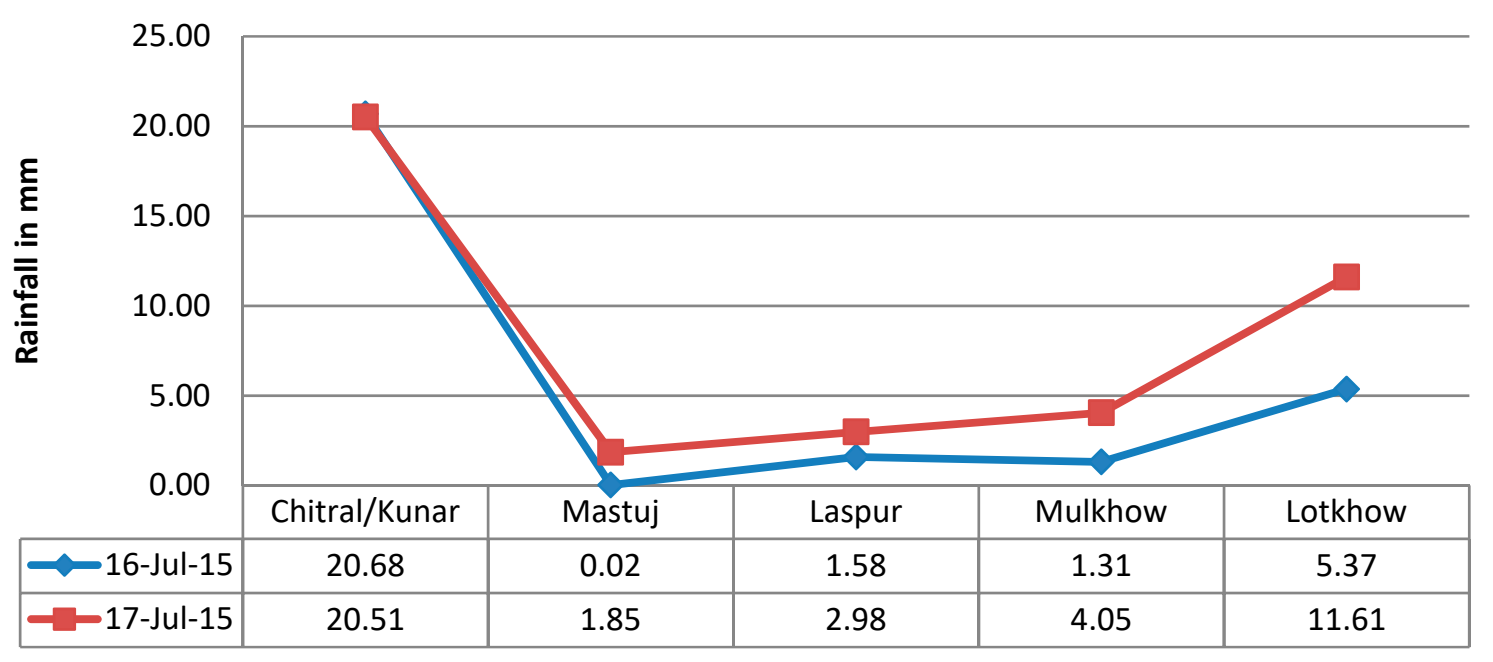

Figure 5: TRMM satellite based rainfall distribution in five sub basins of CRB. 


\subsection{Rainfall-Runoff in HEC-HMS.}

Rainfall-runoff was computed for the five river basins based on SCS curve number (SCS-CN), and SCS unit hydrograph transform methods. The SCS-CN takes into account the effects of land use/cover, soil types, and hydrologic conditions on surface runoff, and it relates direct surface runoff to rainfall. The SCS-CN method has been used for estimating rainfall-generated surface runoff in watershed hydrologic modelling. The results of hydrological modelling peak discharge (CF, cubic feet) for all five sub basins were compared with observation data (Figure 6). The output of each sub basins consists of Time series table, Outflow, Soil infiltration, Excess precipitation, Cumulative excess precipitation, Precipitation loss, Cumulative precipitation loss, and direct flow(Table 1). We used final rainfall-runoff hydrograph and time series data that was populated in an unsteady flow data window to perform flood simulation modelling in the HEC_RAS environment.

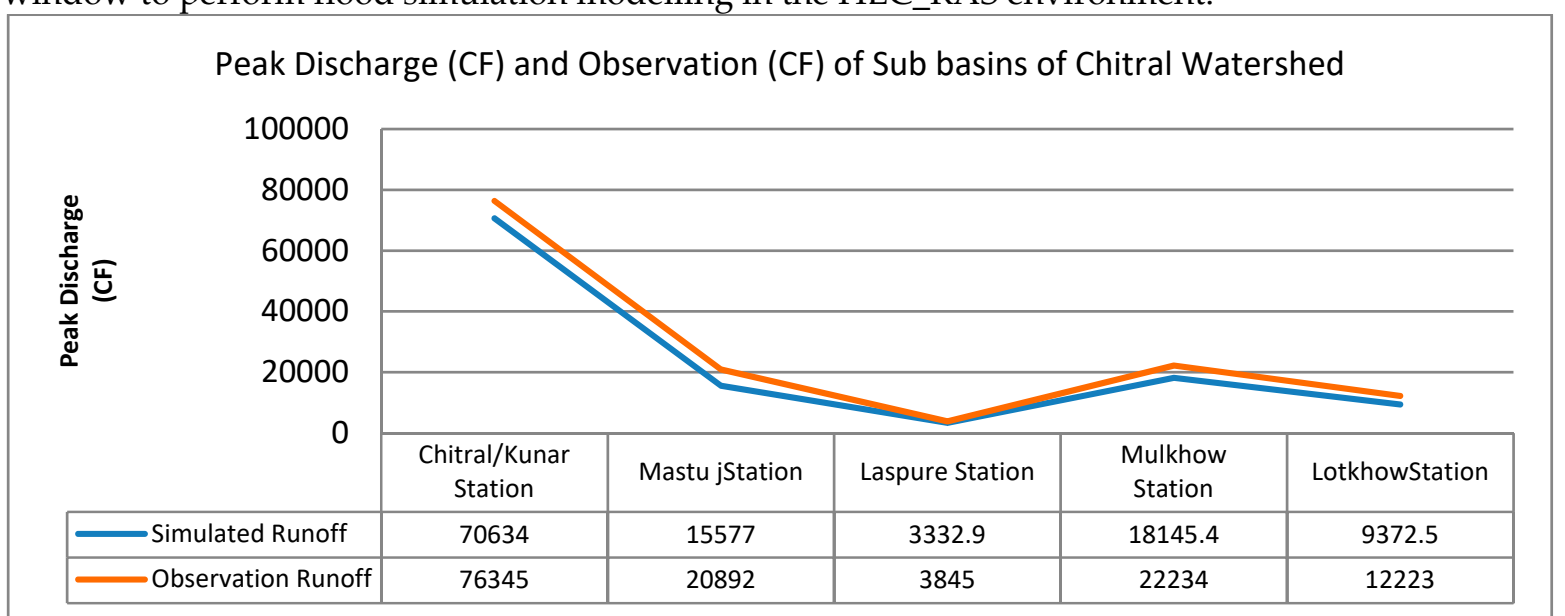

Figure 6: Comparison of simulated and observed runoff of CRBstreams

\begin{tabular}{|c|c|c|c|c|c|c|}
\hline $\begin{array}{l}\text { Sub Basin } \\
\text { Chitral }\end{array}$ & $\begin{array}{l}\text { Direct } \\
\text { Flow }\end{array}$ & $\begin{array}{l}\text { Soil } \\
\text { Infiltration } \\
\text { (IN) }\end{array}$ & $\begin{array}{l}\text { Excess } \\
\text { Precipitation } \\
\text { Depth (IN) }\end{array}$ & $\begin{array}{l}\text { Cum Excess } \\
\text { Precipitation } \\
\text { Depth (IN) }\end{array}$ & $\begin{array}{l}\text { Precipitation } \\
\text { loss } \\
\text { Depth (IN) }\end{array}$ & $\begin{array}{l}\text { Cum } \\
\text { Precipitation } \\
\text { loss } \\
\text { Depth (IN) }\end{array}$ \\
\hline Kunar & 26000 & 0.51 & 0.087 & 0.122 & 0.51 & 1.4 \\
\hline Mastuj & 12000 & 0.53 & 0.064 & 0.089 & 0.53 & 1.5 \\
\hline Laspur & 3200 & 0.57 & 0.041 & 0.059 & 0.55 & 1.8 \\
\hline Mulkhow & 18000 & 0.5 & 0.086 & 0.13 & 0.5 & 1.3 \\
\hline Lotkhow & 9000 & 0.54 & 0.085 & 0.085 & 0.56 & 1.8 \\
\hline
\end{tabular}

Table 1: Show the Hydrological parameter values.

Project: project Simulation Run: Run 591 Junction: Kunar

Start of Run: 16]ul2015, 00:00

Fnd of Run: 16Jul2015, 00:00

17Jul2015, 21:00 Meteorologic Model: Met 1

Compute Time:DATA CHANGED, RECOMPUTE Control Specifications:Control 1

\begin{tabular}{|c|c|c|c|c|c|c|}
\hline Date & Time & $\begin{array}{l}\text { Inflow from KunarBasin } \\
\text { (CFS) }\end{array}$ & $\begin{array}{c}\text { Inflow from Mastuj... } \\
\text { (CFS) }\end{array}$ & $\begin{array}{l}\text { Inflow from Mulkhow... } \\
\text { (CFS) }\end{array}$ & $\begin{array}{l}\text { Inflow from Lotkhow... } \\
\text { (CFS) }\end{array}$ & $\begin{array}{l}\text { Outflow } \\
\text { (CFS) }\end{array}$ \\
\hline 16Jul2015 & $00: 00$ & 0.0 & 0.0 & 0.0 & 0.0 & 0.0 \\
\hline 16 Jul2015 & $03: 00$ & 0.0 & 0.0 & 0.0 & 0.0 & 0.0 \\
\hline 16 Jul2015 & $06: 00$ & 0.0 & 0.0 & 0.0 & 0.0 & 0.0 \\
\hline 16Jul2015 & 09:00 & 0.1 & 0.0 & 0.0 & 0.0 & 0.1 \\
\hline 16Jul2015 & $12: 00$ & 2293.7 & 1326.3 & 1506.5 & 709.5 & 5836.1 \\
\hline 16Jul2015 & $15: 00$ & 4762.2 & 2675.0 & 3134.5 & 1548.2 & 12119.9 \\
\hline 16Jul2015 & $18: 00$ & 1279.7 & 718.0 & 842.4 & 416.9 & 3257.0 \\
\hline 16 Jul20 15 & 21:00 & 251.8 & 141.3 & 165.8 & 82.0 & 640.9 \\
\hline 17Jul2015 & $00: 00$ & 45.3 & 25.3 & 29.8 & 14.8 & 115.3 \\
\hline 17Jul2015 & 03:00 & 653.7 & 365.3 & 430.5 & 216.5 & 1666.0 \\
\hline 17Jul2015 & $06: 00$ & 183.0 & 102.3 & 120.5 & 60.6 & 466.5 \\
\hline 17Jul20 15 & 09:00 & 2379.5 & 1331.0 & 1567.3 & 791.5 & 6069.2 \\
\hline 17Jul20 15 & $12: 00$ & 27539.0 & 15577.0 & 18145.4 & 9372.5 & 70634.0 \\
\hline 17Jul2015 & $15: 00$ & 7654.1 & 4329.8 & 5043.3 & 2605.4 & 19632.5 \\
\hline 17Jul2015 & $18: 00$ & 1503.9 & 850.7 & 990.9 & 511.9 & 3857.6 \\
\hline 17Jul2015 & 21:00 & 295.6 & 167.3 & 194.8 & 100.7 & 758.4 \\
\hline
\end{tabular}

Figure7: Inflow of Mastuj, Laspur, Mulkhow and Lotkhow to Kunar/ CRB 
The total amount of precipitation, precipitation loss, base flow and outflow/Runoff of all five sub basins namely Mastuj, Laspur, Mulkhow and Lotkhow to Kunar/ CRBs are shown in Figures 17-21 in Appendix A.

\subsection{Development of flood maps}

Hydraulic flood maps were developed in an Arc GIS environment. First of all, the data was exported from RAS Mapper of HEC_RAS and then imported into Arc Map to develop the flood depth map of CRB. The maps are based on the 2015 flood discharge data of the five sub streams (Yarkhun stream at Mastuj, Laspur stream at Istordeni, Torkhow stream at Bumbagh, Karimabad stream at Momi and Garamchasma stream at Andakhti villages). The flood depth map shows that the maximum flood depth was 23.168 meters (See Figure 8). The simulated flood of 2015 was classified into three classes on the basis of flood depth (feet). The first class range is 0.03 to 0.42 meters covering $74 \%$ of the flooded area (9809.006 hectares), while the second class is 0.45 to 0.85 meters of depth covering $20 \%$ of the flood area (2600.39 hectares) and the flood depth above 0.85 meters which covered only $7 \%$ of the flood area (900.62 hectares).

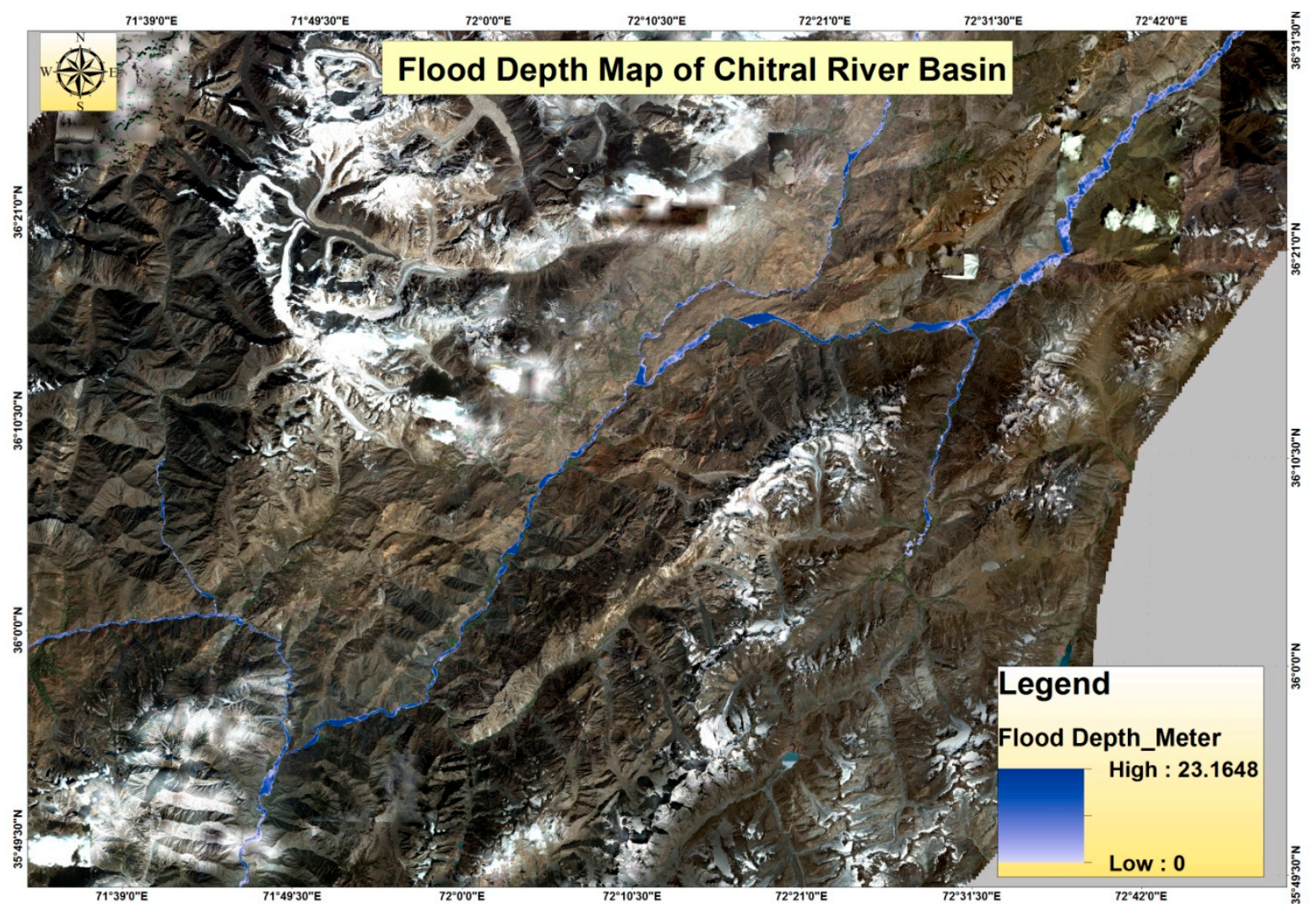

Figure 8: Flood depth map of CRB from the July 16 \& 17, 2015 flood event.

HEC-RAS was used to determine the elevation of a given flood, such as the base flood, and the extent of flooding as well as Hydraulic modelling tools also provided additional helpful information of floodwater velocities. These velocities can be used as design velocities for the development of mitigation measures in target areas. Flood velocity is largely dependent on the slope and roughness of the stream channel and overbank terrain. Water moves downstream faster when channels and overbank areas are steeply sloped. Water also flows faster over paved or smooth surfaces such as roadways or parking lots as opposed to densely vegetated stream banks. Streams in steep or mountainous areas tend to have higher floodwater velocities that are capable of more damage than those in flatter areas [52]. Figure 9 shows the flood velocity map of the CRB. The maximum speed of flooding was 34 meters per second. Flood velocities of CRB streams were measured at specific sites such as Yarkhun stream at Mastuj, Laspur stream at Istordeni, Torkhow stream at Bumbagh, Karimabad stream at Momi and Garamchasma stream at Andakhti villages during this flood. 


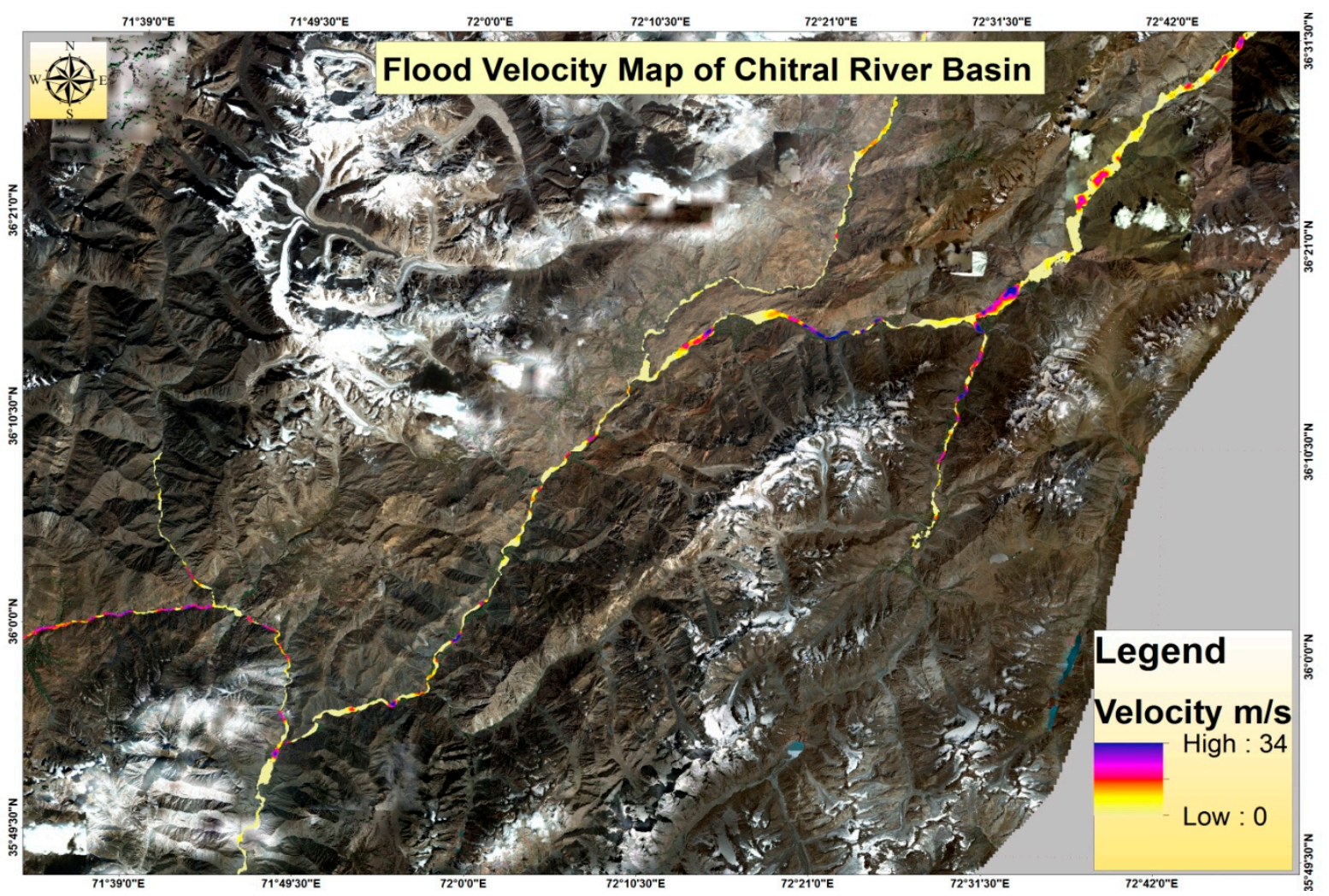

Figure9: Flood velocity Map of the CRB streams.

Flood hazard maps of CRB were developed by combining the flood depths and velocity surfaces. First, the integrated surface of flood depth and velocity were developed in RAS Mapper and exported. Then, this surface data were imported into arc maps and layouts were made. Hazard zones were classified into three hazard types: high is shown in red, medium is shown in orange and low in Green. Sixty percent of the flood area (8000.2 hectares) is high hazard, 31\% (4130.20 hectares) were classified as medium hazard and $9 \%$ (1179.8hectares) of the flood area is low (See Figure 10).

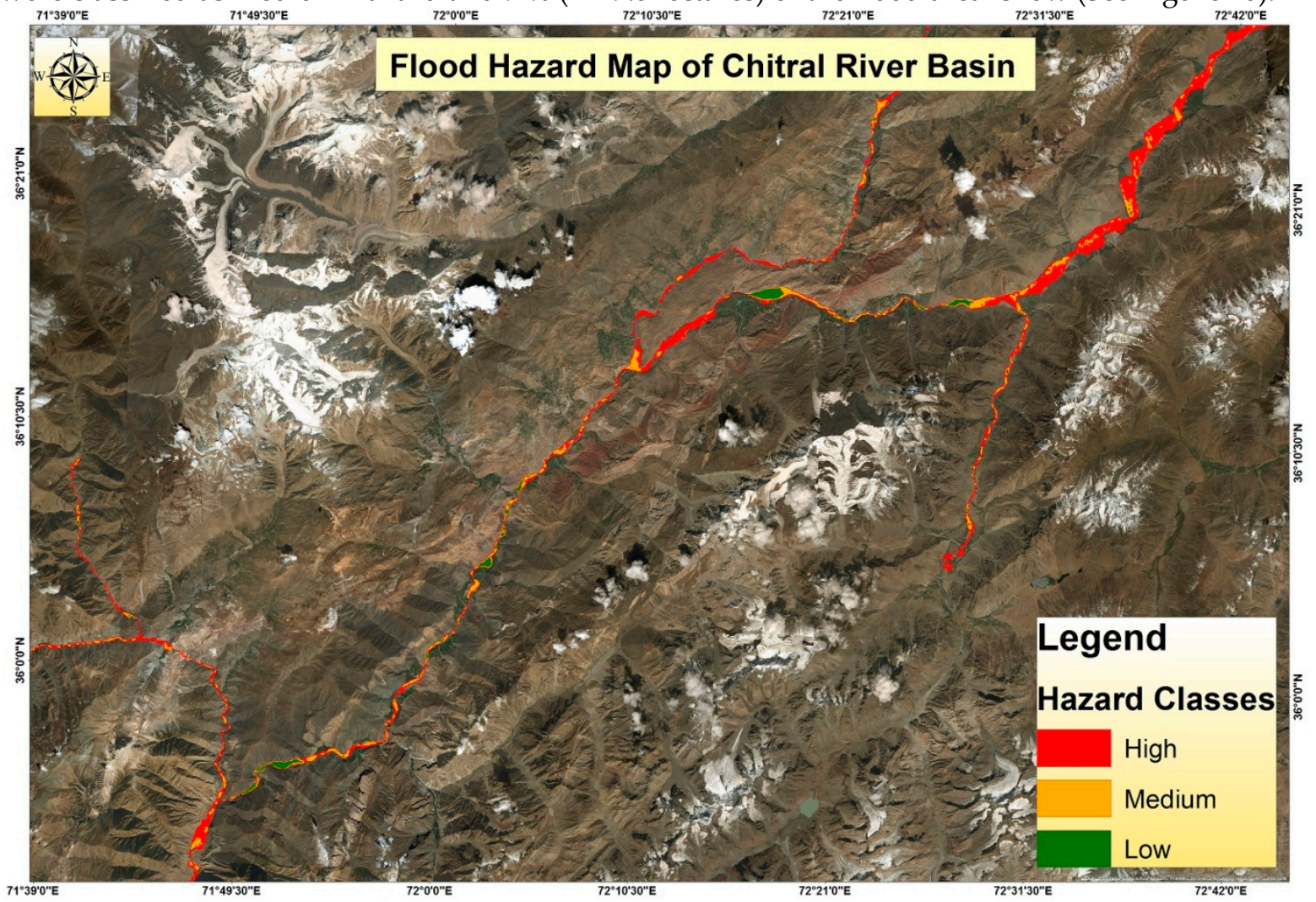

Figure 10: Flood Hazard Map with hazard classifications of High, Medium and Low 
A Flood risk map of the CRB was developed in Arc Map through overlaying bridge point data and roads in line shape files onto the flood hazard zone (see Figure11). This flood risk map only shows the bridges and road sections which were exposed to the flood. The exposure of bridges and roads to flooding were calculated using the intersect tool of arc Map. A total of 60 bridges were exposed to simulated floods in the Chitral district, 10 bridges exposed in Chitraltehsil, 14 inLotkhow, 9 in Mulkhow, and 27 in Mastujtehsil.

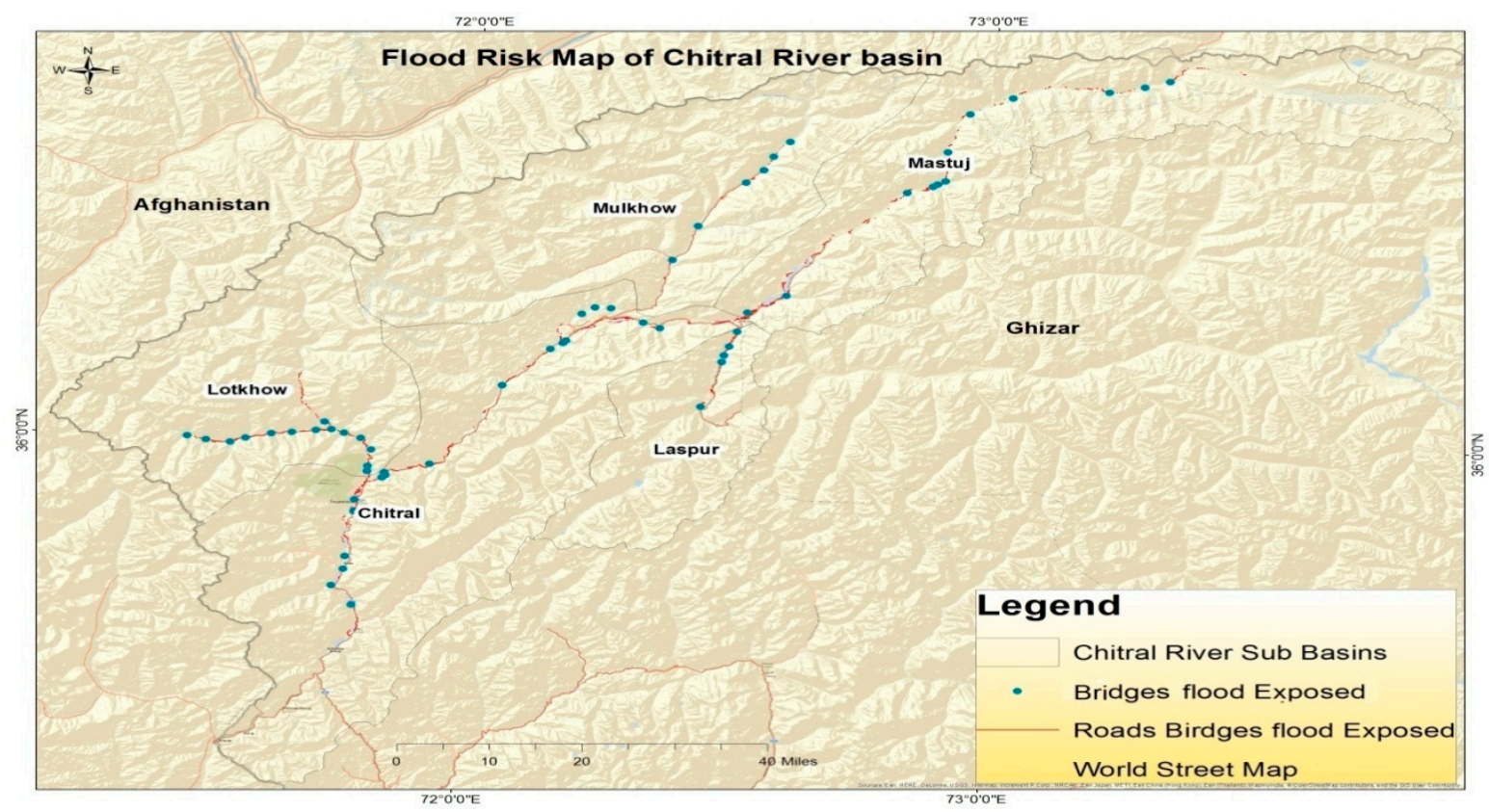

Figure 11: Flood risk map including at risk bridges and road sections in CRB.

\subsection{Flood Arrival Time}

Time arrival information of a flood is very crucial for mountainous area. This has been used as an early warning for the evacuation of people from flood hazardous areas. Flood arrival time is directly related to the topography of the area, land use land cover properties and the volume of water. The time arrival of flood water increases in steep slope areas while it decreases in plains areas. Chitral watershed has very rough topography. The time arrival of flood varies within the five sub basins. Figure 12 shows the flood arrival time in hours versus the submerged area in sq $\mathrm{km}$ of sub the Chitral watershed sub basin. The flood submerged $47.7 \mathrm{sq} \mathrm{kms}$ within $24 \mathrm{hrs}, 37.2 \mathrm{sq} \mathrm{kms}$ from 25 to $36 \mathrm{hrs}$ and by 36 hours it submerged $79.3 \mathrm{sq} \mathrm{kms}$.

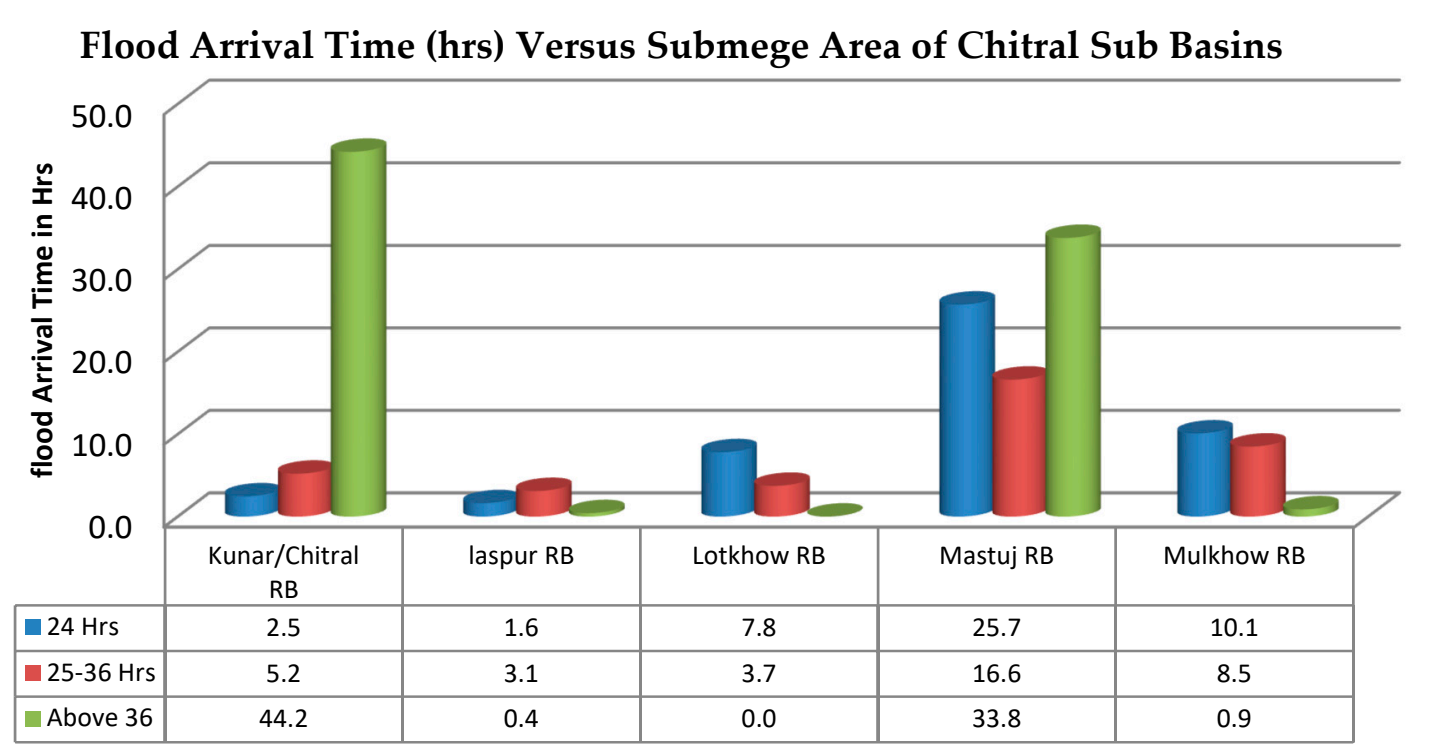

Figure 12: Shows the flood arrival time verse submerge area in sq $\mathrm{km}$ of Chitral sub basins. 


\subsection{Calculation of Flood Exposure}

Flood hazard exposure was calculated using an intersection process of flood hazard zones with LULC as well as road and bridge shaped files. The intersection results were exported to Microsoft Excel for the development of graphs and tables. LULC flood exposure (Table2) shows the exposure of settlement, agricultural land, barren land, forest, shrubs and bushes, river beds and water bodies in hectares. Roads exposed to flooding were calculated in kilometres in the Chitral sub river basin and bridges exposed to flood were also calculated. The flood exposure shows that Mastujtehsil has more road infrastructure exposure at approximately 124 kilometres, Lotkhowtehsil has $90 \mathrm{~km}$ of road exposed and Mulkhow and Torkhowtehsil have 24 kilometres and Chitraltehsil has 20 kilometres of road exposed to flooding.

Table 2: Simulated flood exposure as per July 16 \& 17, 2015 flood event in CRB.

\section{FID}

\section{Provinces}

2 khyberpakhtunkhwa (KP)

1 khyberpakhtunkhwa (KP)

3 khyberpakhtunkhwa (KP)

4 khyberpakhtunkhwa (KP)

6 khyberpakhtunkhwa (KP)

7 khyberpakhtunkhwa (KP)

8 khyberpakhtunkhwa (KP)

\section{District}

\section{LULC Flood Exposure}

Settlements

Agriculture Land

Chitral

Chitral

Chitral

Chitral

Chitral

Chitral
Barren Land

Forest

Shrubs And Bushes

River Beds

Water Bodies
Hectares

180.0

3298.2

2035.2

684.3

1575.3

5535.7

1.513846

Total flood exposure

13310.1

320

321

322

323

324

325

326

327

328

329

330

331

\subsection{Validation of flood results.}

Validation of flood depth was carried out using the flood depth data and flood duration data which were collected in cooperation with AKRSP, and were compared with simulated hydraulic flood depth measured in RAS Mapper. For the correlation of real and simulated flood depth, we measured and compared the field measured depth of flooding at the same locations within the RAS Mapper environment (coordinates X, Y), and those acquired from field camps during the July 16 and 17, 2015 flooding. The results of the simulated flood and real flood show a close relationship, but there is an increase in the real flood depth while the simulation data shows a decrease in depth. This is caused by low resolution DEM and the lack of high resolution digital terrain model (DTM) data. The validation statistics are shown in Table 3 .

Table 3: Validation statistics of real flood and simulated flood of July 2015 in CRB

$\begin{array}{ccccc}\text { Sub stream } & \text { Location } & \begin{array}{c}\text { Real Flood } \\ \text { Mean depth(meter) }\end{array} & \begin{array}{c}\text { Simulated Flood } \\ \text { Mean depth(meter) }\end{array} & \text { Error } \\ \text { Laspur River } & \text { Istordeni } & 6.4 & 5.3 & 1.1 \\ \text { Yarkhun) } & \text { Mastuj } & 7.5 & 6.7 & 0.8 \\ \text { Lotkhow } & \text { Bumbagh } & 8.8 & 7.6 & 1.1 \\ \text { Karimabad } & \text { Momi } & 7.1 & 7.0 & 0.1 \\ \text { Garamchasma } & \text { Andakhti } & 6.0 & 5.5 & 0.6\end{array}$




\subsection{Uncertainty Analysis}

As discussed above, the TRMM rainfall, HEC-HMS and HEC-RAS based method has the capacity for flood modelling in mountainous regions without river gauges and weather stations. In this study we have calculated the rainfall from TRMM data, rainfall-runoff in HEC-HMS and hydraulic flood simulation in HEC-RAS. The results of flood modelling could be used as useful information for emergency response and flood mitigation purposes. Uncertainty analysis of the TRMM rainfall data, rainfall-runoff, flood depth and velocity are critical for the improvement of flood prediction capabilities. Uncertainty in flood inundation mapping arises from input data as well as modelling approaches including hydraulic modelling, hydrologic modelling, and terrain analysis. Although the variables contributing to uncertainties in flood inundation mapping are well documented by several studies [54-57], the accuracy of TRMM rainfall, hydrological runoff and hydraulic results i.e. flood depth and velocity is determined by the uncertainty method (fundamental measurement method).

I. Measured Error.

II. standard deviation

III. Distribution Variance

IV. Distribution Standard Deviation

V. Measurement Uncertainty

Measurement error is the difference between a measured value and the "true" value

$$
\mathrm{x}_{\text {measured }}=\mathrm{x}_{\text {true }}+\varepsilon_{\mathrm{x}}
$$

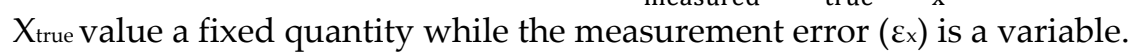

Standard deviation is the spread of an error distribution. The standard deviation is the square root of the distribution variance

Standard deviation $\quad=\quad \operatorname{Varx}$ measured $)=\operatorname{Var}\left(\varepsilon_{\mathrm{x}}\right)=\varepsilon_{\mathrm{x}} 2^{-}$

Distribution Variance $\left.\quad=\quad \operatorname{Varx}_{\text {measured }}\right)=\operatorname{Var}\left(\mathrm{x}_{\text {true }}+\varepsilon_{\mathrm{x}}\right)=\operatorname{Var}\left(\varepsilon_{\mathrm{x}}\right)$

Distribution Standard Deviation $=\sigma_{\mathrm{x}}=\sigma \varepsilon_{\mathrm{x}}=\sqrt{\operatorname{Var}\left(\varepsilon_{\mathrm{x}}\right)}$

Measurement Uncertainty $\quad=\quad \mathrm{u}_{\mathrm{x}}=\sigma_{\mathrm{x}}=\sigma \varepsilon_{\mathrm{x}}=\mathrm{u}_{\varepsilon_{\mathrm{x}}}$

Rainfall uncertainty was calculated through a fundamental measurement method using TRMM rainfall data of 16 and 17 July and average rainfall data of July from 2000 to 2015 which was acquired from Pakistan Meteorological Department (PMD). The average measurement error is 13.994, standard deviation 16.268, distributed variance 30.262, distribution standard deviation 30.262 and measurement uncertainty is \pm 16.26 . We have also calculated the uncertainty of TRMM rainfall data using Uncertainty Sidekick software (Figure: 13).

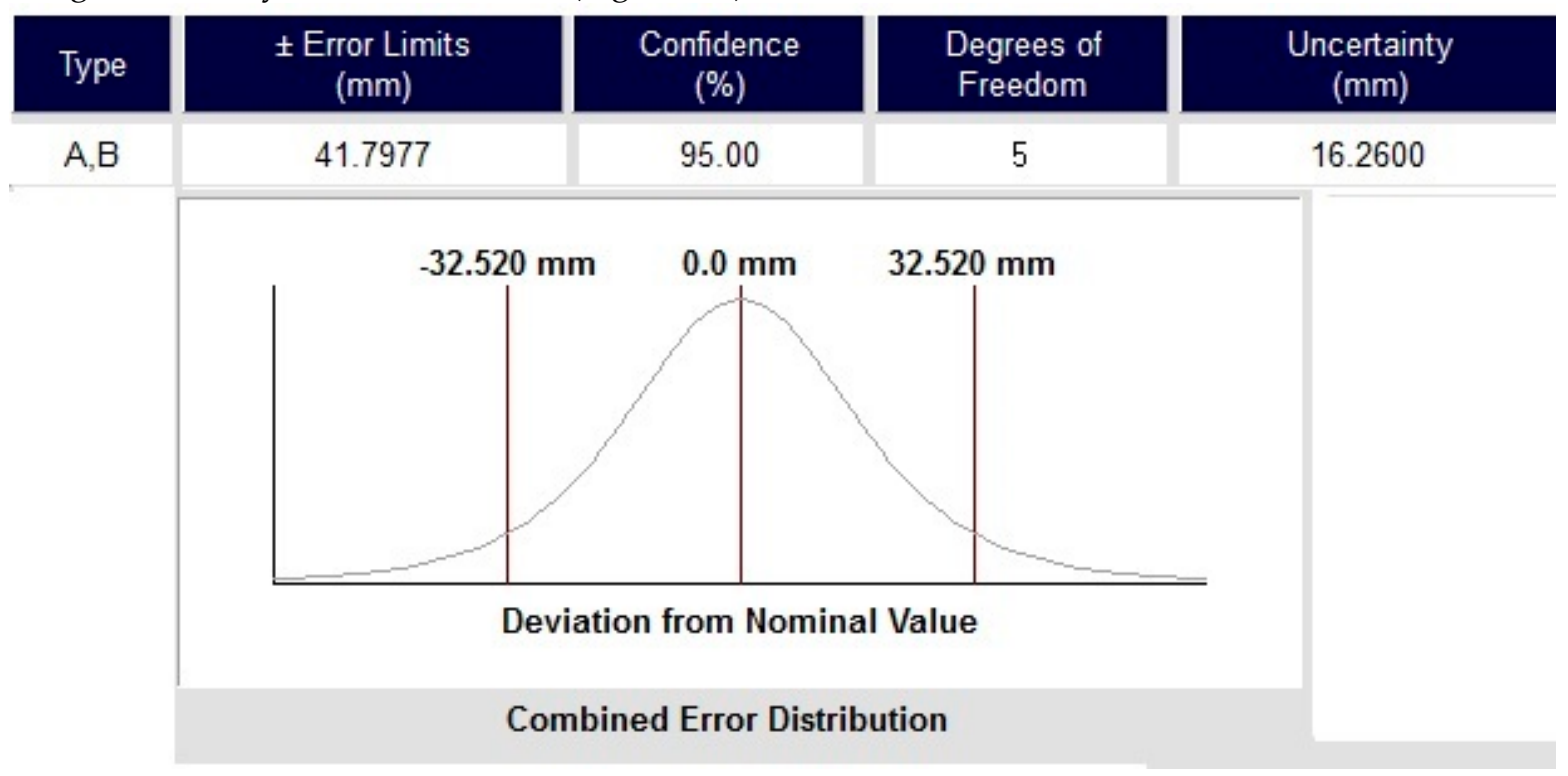


The result of velocity uncertainty through this fundamental measurement method shows the average measurement error is 1.002; standard deviation 0.76; distributed variance 1.76; distribution standard deviation 0.577 and measurement uncertainty is \pm 0.760 . The results through uncertainty of TRMM rainfall data using Uncertainty Sidekick are shown in Figure 14.

\begin{tabular}{|c|c|c|c|}
\hline Type & $\begin{array}{l} \pm \text { Error Limits } \\
(\mathrm{m} / \mathrm{s})\end{array}$ & $\begin{array}{c}\text { Confidence } \\
(\%)\end{array}$ & $\begin{array}{l}\text { Degrees of } \\
\text { Freedom }\end{array}$ \\
\hline$A, B$ & 0.9634 & 95.00 & 4 \\
\hline & & $0.0 \mathrm{~m}$ & $0.694 \mathrm{~m} / \mathrm{s}$ \\
\hline & \multicolumn{3}{|c|}{ Deviation from Nominal Value } \\
\hline & \multicolumn{3}{|c|}{ Combined Error Distribution } \\
\hline
\end{tabular}

Figure:14 show the uncertainty result of Flood Velocity using Uncertainty Sidekick

The result of flood depth uncertainty through fundamental measurement method: average measurement error is7.16; standard deviation 1.09; distributed variance 8.25; distribution standard deviation 1.18 and measurement uncertainty is \pm 1.09 . The results of the uncertainty of flood depth using Uncertainty Sidekick is shown in Figure 15.

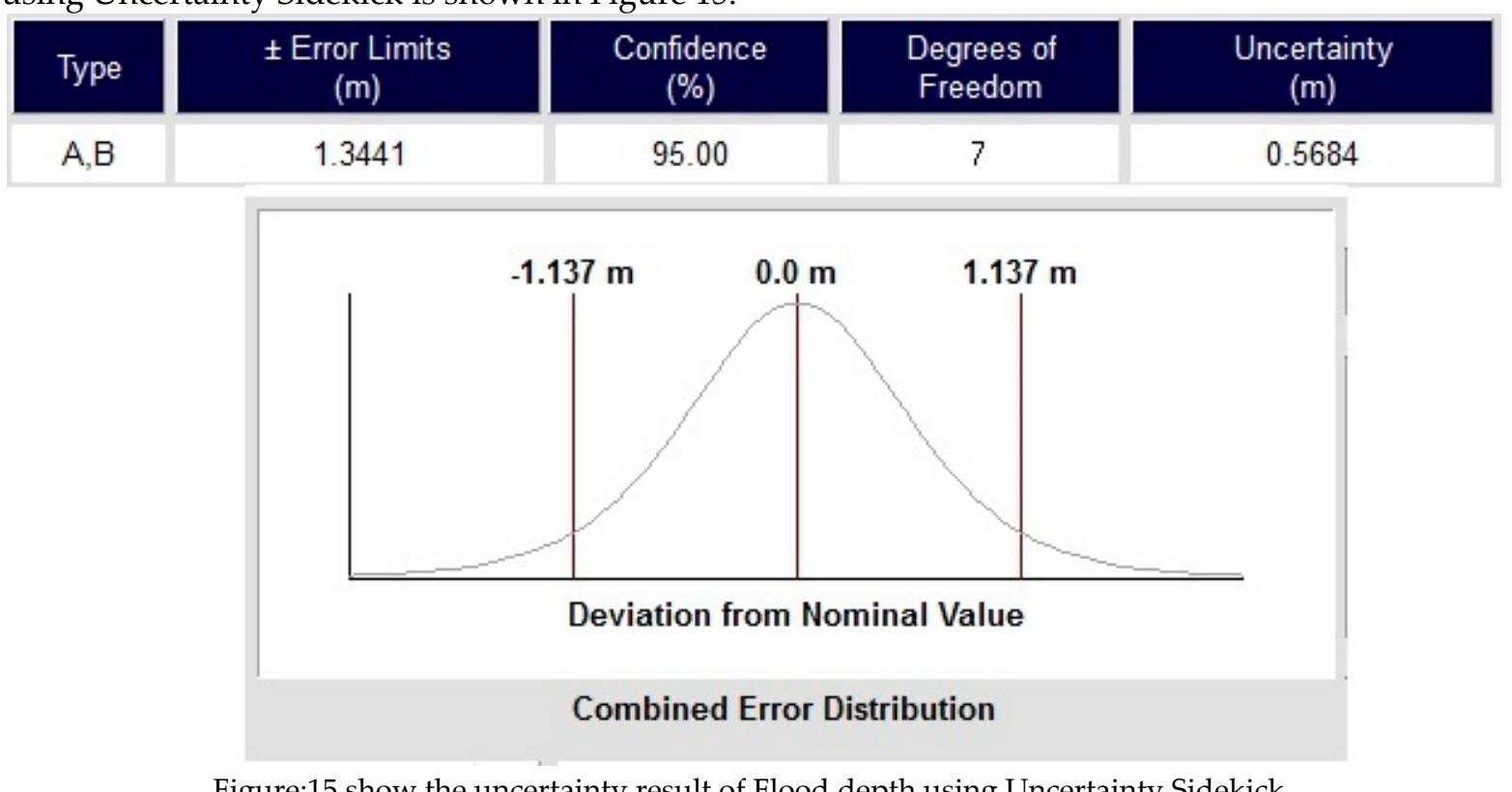

Figure:15 show the uncertainty result of Flood depth using Uncertainty Sidekick

The rainfall-runoff uncertainty according to fundamental measurement method: average measurement error is 44.27; standard deviation 28.93; distributed variance 336.01; distribution standard deviation 837.20 and measurement uncertainty is \pm 28.93 (see Figure16.The uncertainty result of TRMM rainfall has close agreement in both methods of uncertainties. While other parameter like flood depth, Velocity and rainfall-runoff has some deviation between the fundamental 


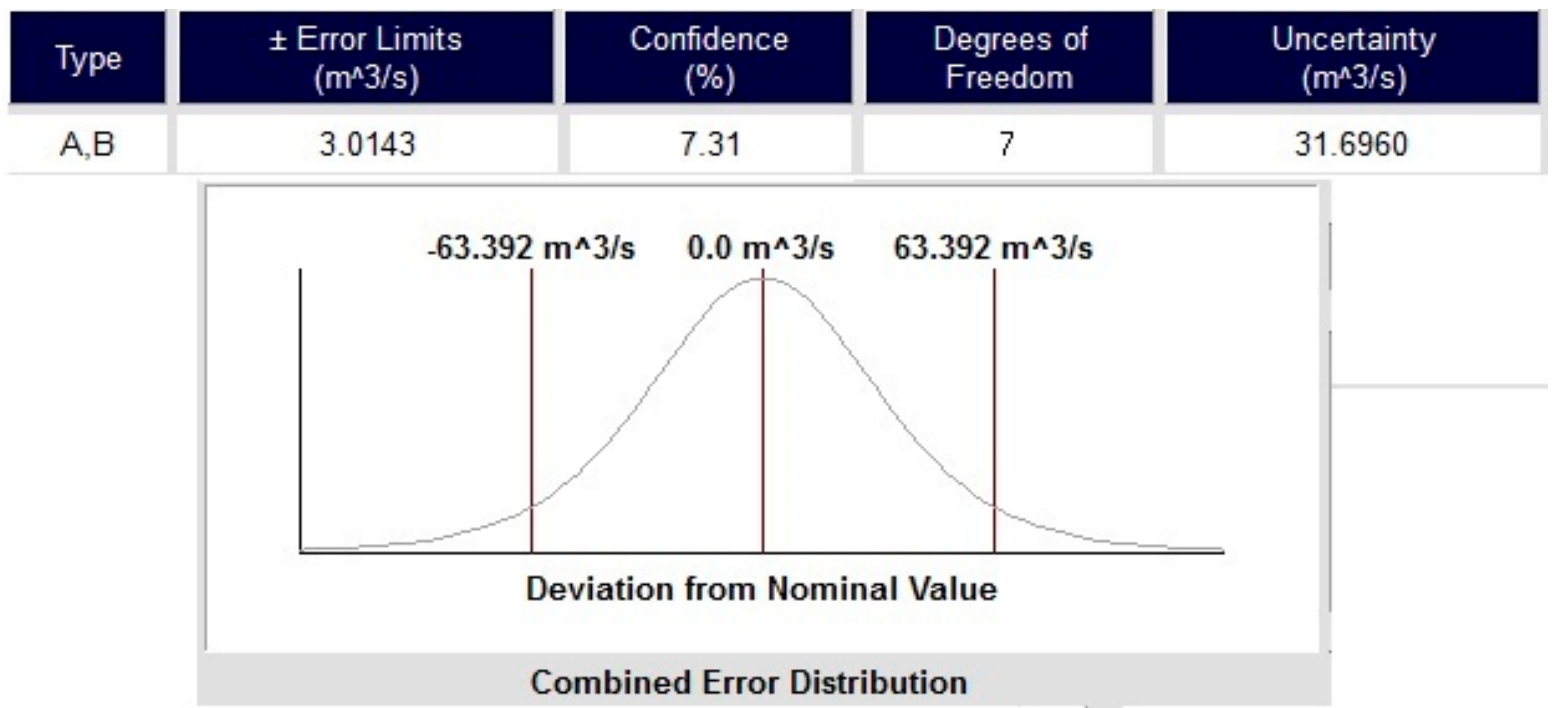

Figure: 16 show the uncertainty result of rainfall-runoff using Uncertainty Sidekick

Uncertainty analysis of the TRMM rainfall data, rainfall-runoff, flood depth and velocity are combined and presented in the Table 4.

Table 4: Uncertainty analysis of the TRMM rainfall data, rainfall-runoff, flood depth and velocity

\begin{tabular}{|c|c|c|c|c|c|c|c|}
\hline Parameters & $\begin{array}{l}\text { Average } \\
\text { Measured }\end{array}$ & $\begin{array}{c}\text { Measurement } \\
\text { Error }\end{array}$ & $\begin{array}{c}\text { Distribution } \\
\text { Variance }\end{array}$ & $\begin{array}{l}\text { Standard } \\
\text { Deviation }\end{array}$ & $\begin{array}{c}\text { Distributed } \\
\text { Variance }\end{array}$ & $\begin{array}{l}\text { Standard } \\
\text { Variance }\end{array}$ & $\begin{array}{r}\text { Measurement } \\
\text { Uncertainty }\end{array}$ \\
\hline TRMM rainfall & 13.99 & 41.19 & 264.65 & 16.27 & 57.46 & 264.65 & 16.27 \\
\hline Rainfall-Runoff & 44.27 & 86.45 & 837.20 & 28.93 & 115.38 & 837.20 & 28.93 \\
\hline Flood Velocity & 1.00 & 1.72 & 0.58 & 0.76 & 2.48 & 0.58 & 0.76 \\
\hline Flood Depth & 7.16 & 6.40 & 1.18 & 1.09 & 7.49 & 1.18 & 1.09 \\
\hline
\end{tabular}

The measurement error of TRMM rainfall is 41.19 , which is a large gap affected by the uncertainty of TRMM rainfall data. This large gap is related to the large difference between the average rainfall data for the month of July in the years of 2001 to 2015 (acquired from PMD) and the TRMM rainfall data of July 16 and 17, 2015. The isolated thunder rainfall occurred in Chitral River, but no rainfall occurrences were recorded at the PMD weather station, which is located in this area. This rainfall on those 2 days in July 2015 broke all preceeding rainfall records. The rainfall was 0.61 times more than the average observed rainfall that was documented from 2001 to 2015. The generated flash floods and

404 debris flow of this July 16 and 17 event damaged a significant number of infrastructures, roads, bridges, agricultural fields and houses. 


\section{Discussion}

Chitral River is a tributary of the Kabul River and the second largest river in Pakistan. The Chitral River is fed by snow and glacier melt and receives much of the snowfall during the winter (Dec to Feb) and pre monsoon (April to May) seasons. During monsoons, discharge data from thunderous rain storms causes floods, flash floods and GLOF [53].Historically, Chitral watershed has been affected by devastating flood events. The 2015 flood event was devastating in the history of Chitral. The lack of weather stations data and river gauges data coupled with the rough mountain topography caused difficulties for properly calibrating and validating a flood model. To address these issues, we have developed a remote sensing base flood model. The results show that our methods can be used for future flood management practices in mountainous regions where there is limited observation data.

The flood model was developed using remote sensing TRMM based rainfall data from July 16 and 17, 2015 in the CRB. This TRMM rainfall data were used for the calculation of rainfall-runoff in HEC-HMS environment and hydraulic flood modelling was performed in HEC-RAS using simulated discharge hydrograph and time series runoff data was prepared in HEC-HMS. The results of hydraulic flood modelling are flood inundation boundaries, flood depth and height and flood velocity surfaces as well as flood exposure and elements at risk in the sub-rivers: Mastuj, Laspur, Mulkhow, Chitral and Lotkhow. We have compared the simulated flood results with the damage of the July 2015 flood in CRB.

We used TRMM 3B42 precipitation data for those two days. This data product consists of TRMM TMPA Rainfall, which merged satellite rainfall estimates (S) and gauge data $(G)$. This was used to extract the isolated thunder rain storm in the entire CRB region. TRMM is a favourable alternative to conventional precipitation observations using rainfall gauges. TRMM data provides real time distributed data which have improved research results in the field of hydrological modelling [26-28].The sub basins of Chitral watershed received different amounts of TRMM rainfall within 16 and 17 July, 2015.Kunar/Chitral, the largest sub basin which covers 37\% of Chitral watershed area, received $41.2 \mathrm{~mm}$ rainfall. Mastuj, covering $11 \%$, received $1.9 \mathrm{~mm}$, Laspur $(5 \%$ )received $4.6 \mathrm{~mm}$ while Lotkhow which covers $21 \%$, received $17 \mathrm{~mm}$ and Mulkhow which covers $26 \%$, received only $5 \mathrm{~mm}$ of rainfall. This variation is due to the isolated thunder rainfall pattern on those two days in the Chitral watershed. The Mulkhow is the second largest basin, but it received less rainfall than Lotkhow basin. This is due to the low rainfall occurrence. That is why the rainfall-runoff was also low in Mulkhow, Laspur and Mastuj while it increased in Kunar/ Chitral river basin and Lotkhow river basin as per the results of HEC-HMS. The validation results of HEC-HMS based discharge data have a close agreement with the load observation data of July $16-17,2015$, acquired from AKRSP organization. The agreement statistic of simulated discharge and real flood discharge: Chitral/Kunar basin has $92 \%$, Laspur basin $87 \%$, Mulkhow $82 \%$, Lotkhow $77 \%$ and Mastuj basin $75 \%$. These HEC-HMS based discharge hydrographs and Time series flow data was used for flood inundation mapping in HEC-RAS environment.

We have validated the results of simulated hydraulic flood in two ways. First, we compared the simulated flood zones with available flood damage on July 16 and 17, 2015. The flood damage data were acquired from Provincial Disaster Department Authority (PDMA), FOCUS Pakistan and Provincial Reconstruction and Rehabilitation and Settlement Authority. Real flood damaged $40 \mathrm{~km}$ of road sections, 60 bridges and 1200 acres of standing crops in the entire Chitral river basin while the simulated flood shows that a total of 60 bridges, 262 kilometres of road, $01 \%$ of urban area, $25 \%$ of agriculture along the Chitral River from the Chanter glacier to Osiak village are in the flood impact zone. Secondly, we have verified the simulated flood with real flood through flood depth stack (height)at five locations in CRB. Validation of flood depth was carried out in RAS Mapper and Arc Map 10.2.2 environment. We measured the depth of flood in the same locations in RAS Mapper environment with respective locations of the real flood depth data using coordinates $\mathrm{X}, \mathrm{Y}$. Results of simulated flooding and real flooding show a close relationship, but there is an increase in the depth of the real flood while the simulation data show a decrease in depth. This may be largely due to the unavailability of high resolution DTM data. The validation statistics were shown in Table2. 
After completing the hydraulic analysis of Chitral River and its floodplain, efforts were made to reduce the errors in data and results through validating them with round data. The main limitation resides in low resolution DEM. It is the base topography or terrain on which the analysis was performed. Unavailability of updated land use land cover data is a gap that needs to be filled in order to calculate the actual river floodplain roughness value. It is possible to delineate the highly accurate flood zonation using high resolution digital terrain data set with updated LULC data of the Chitral district.

\section{Conclusions}

CRB has experienced devastating flood events in the past, but there were neither hydraulic modelling nor mapping zones available for the entire CRB. This study presents an integrated methodology for regional scale flood modelling that integrates the available TRMM satellite data, GIS, hydrological HEC-HMS and hydraulic HEC-RAS models. The flood model is appropriate for regional studies especially for rough mountainous areas where there is no local rainfall observation data or river discharge gauges. The result of flood modelling based on remote sensing rainfall data will be useful for developing regional flood early warning and flood mitigation systems in flood hazardous areas along the Chitral River. The present study, including the flood simulation video could be used for disaster preparedness training in communities living in the Chitral district. This approach will increase the coping and adaptive capacity of the local population against the impact of future floods. This research and methodology could be applicable for other locations which need to conduct hydrological and hydraulic studies. Incorporating the local stakeholders and geographic and weather conditions are essential to this modelling process.

\section{Patents}

Supplementary Materials: Supplementary data related to this research is also available at https://www.ckrb.org/. It includes the TRMM data and Hydraulic flood Simulation video

Author Contributions: In this paper, all the authors contributed to data collection, pre-processing of data sets, development of methodology, analysis and drafting of the research paper.

Funding: This research received funding from the Partnerships for Enhanced Engagement in Research (PEER) cycle 5, under project 'Satellite enhanced snow-melt flood and drought predictions for the Kabul River basin with surface and groundwater modelling'

Acknowledgments: Authors acknowledge the financial support of Partnerships for Enhanced Engagement in Research (PEER) cycle 5 project Grant Award Number AID-OAA-A-11-00012; titled 'Satellite enhanced snow-melt flood and drought predictions for the Kabul River basin with surface and groundwater modelling'. We are extremely thankful to Zeeshan Ali "Manager Infrastructure \& Renewable Energy of Aga Khan Rural Support Programme (AKRSP) Pakistan", who provided the 2015 flood discharge data. We also acknowledge the USGS from where we downloaded the Digital elevation Model (DEM) and TRMM data that were used for the precipitation calculations.

Conflict of Interest: There is no conflict of interest.

\section{Appendix A}

These Figures shows the detail of hydrological modelling results of sub basins of CRB.The sub basins includeKRBMastujLaspurMulkhowLotkhow 


\section{Kunar River basin/CRB}
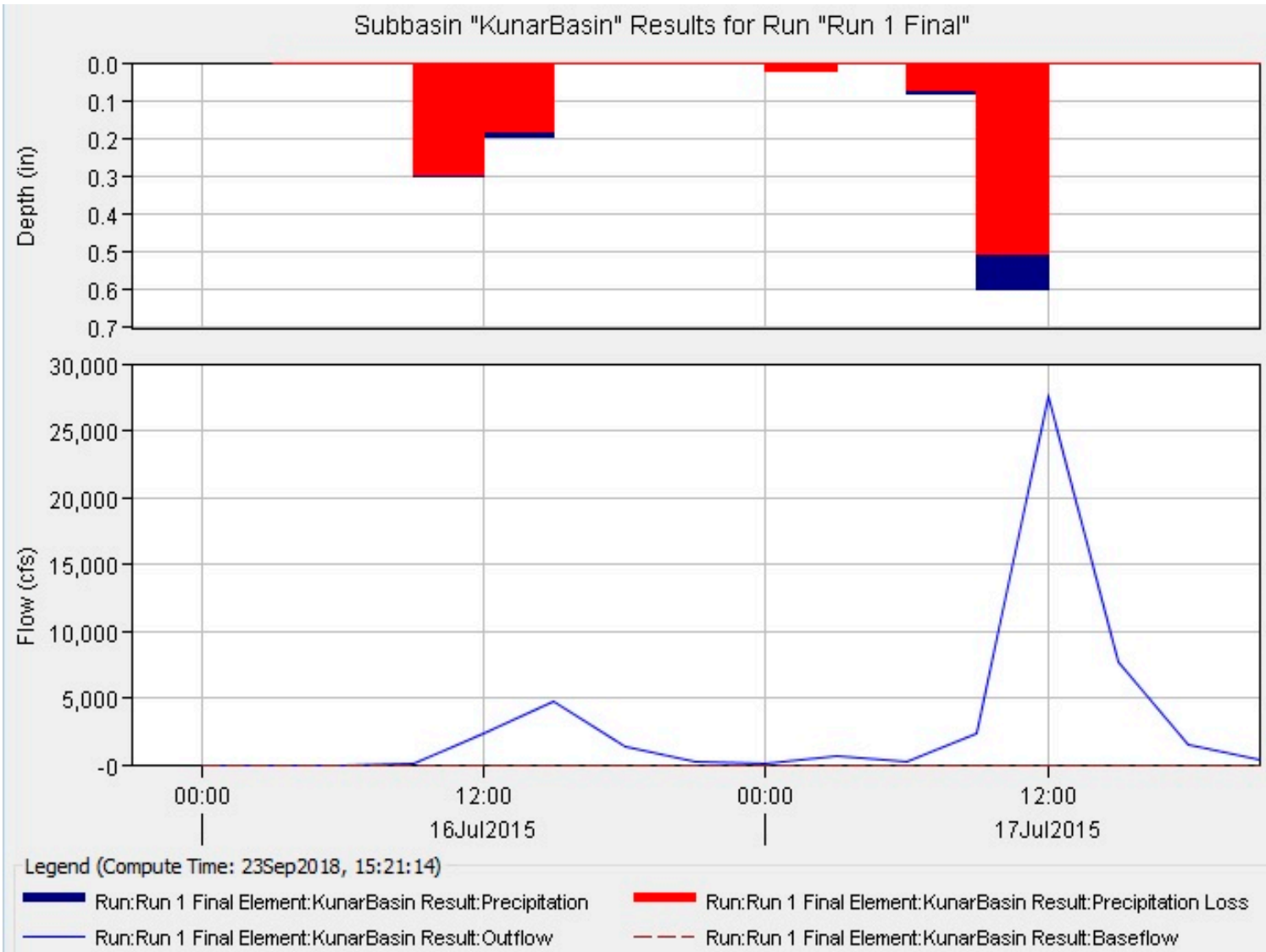

500 Mastuj River Basin

Subbasin "Mastuj" Results for Run "Run 1 Final"
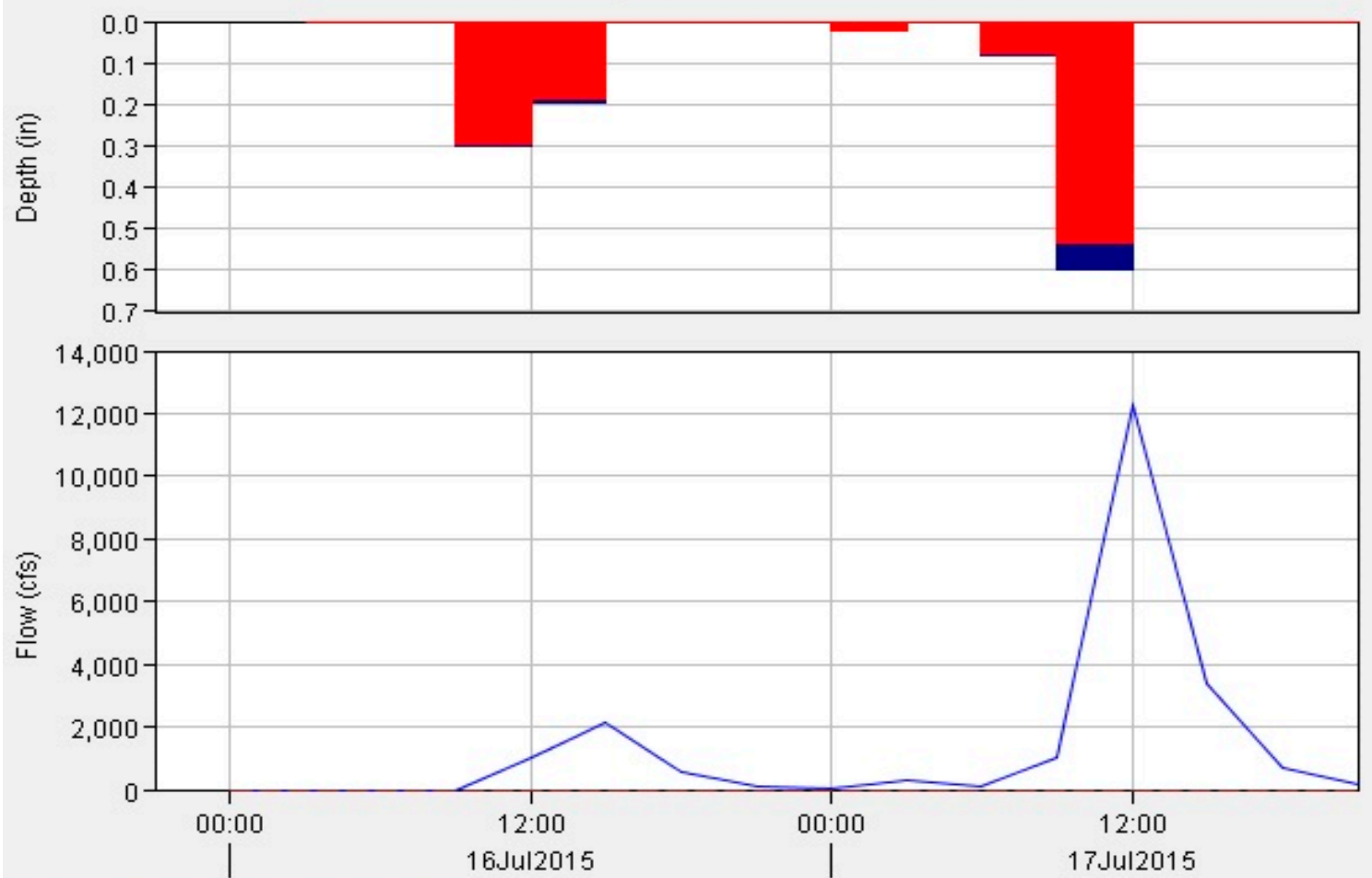

Legend (Compute Time: 23Sep2018, 15:21:14) 


\section{Laspur}

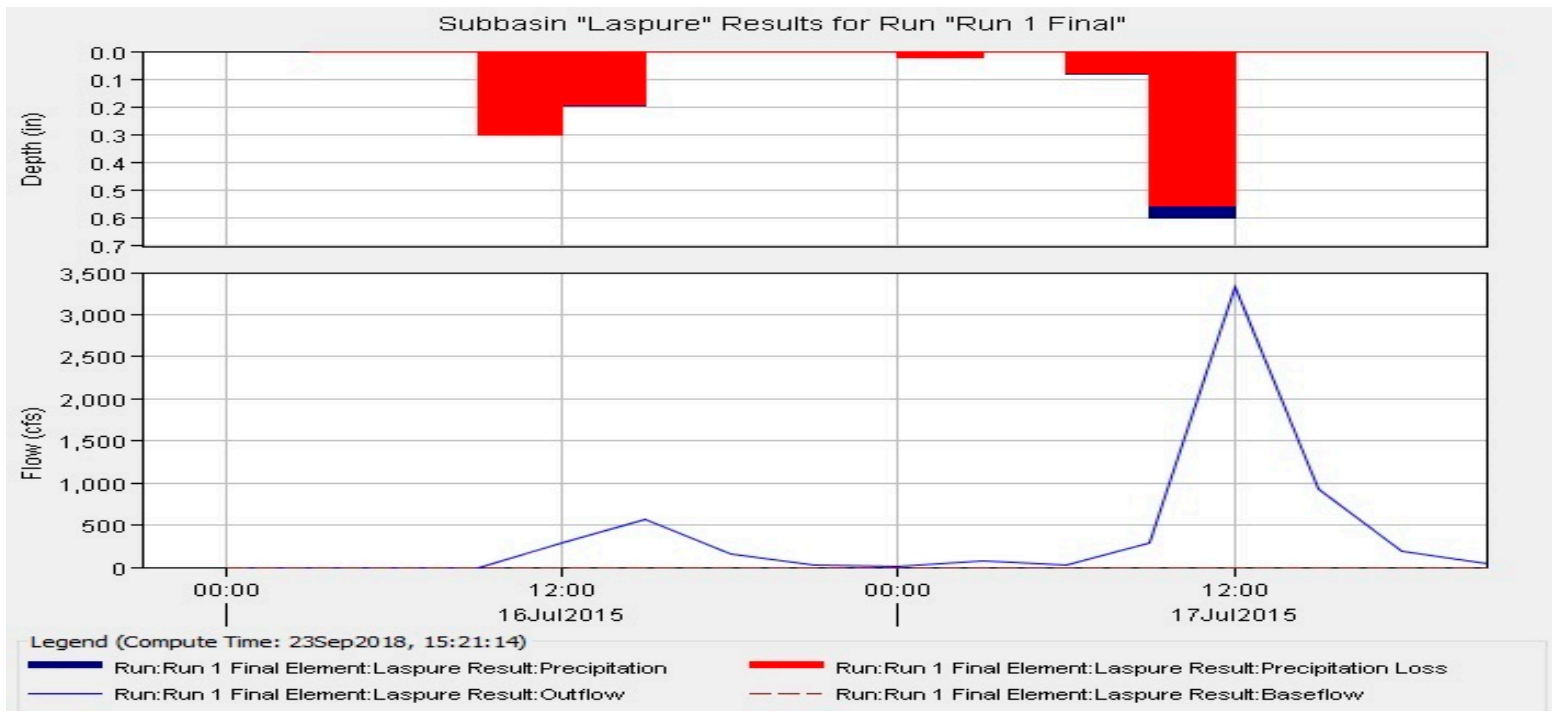

\section{Mulkhow}

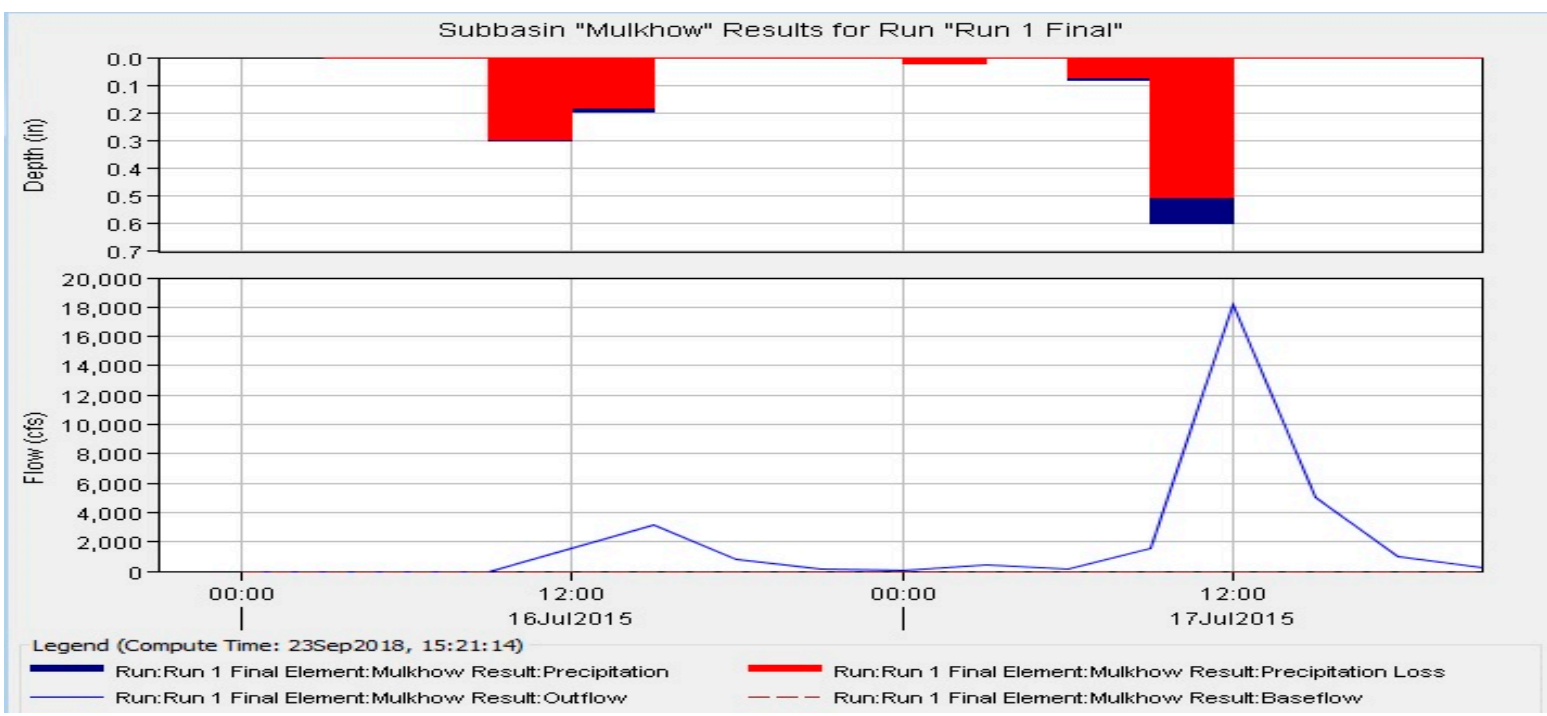

\section{Lotkhow}

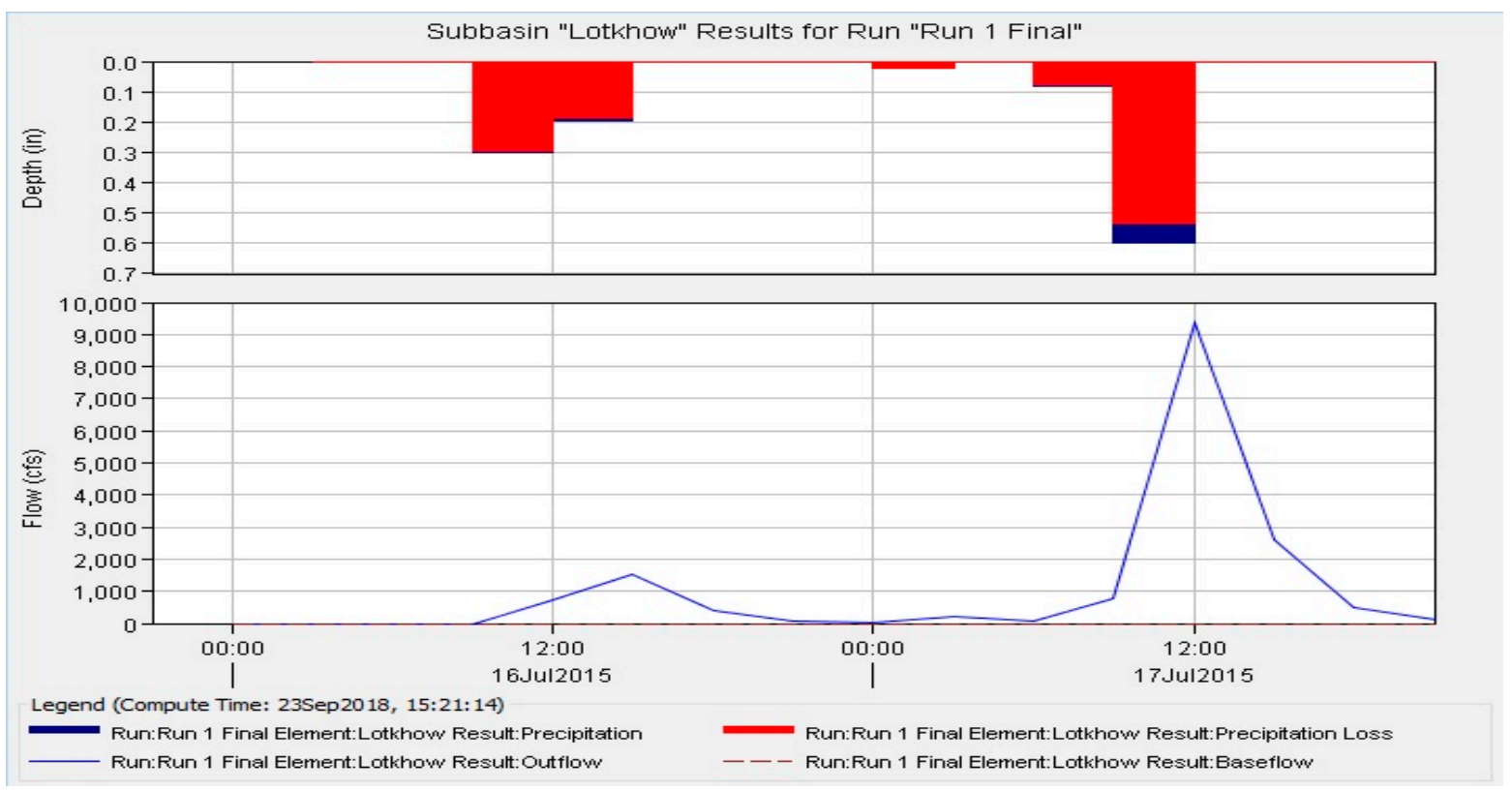




\section{References}

1. Hudson, P. F., \&Colditz, R. R. (2003). Flood delineation in a large and complex alluvial valley, lower Panuco basin, Mexico. Journal of Hydrology, 280(1-4), 229-245.

2. Knebl, M. R., Yang, Z. L., Hutchison, K., \&Maidment, D. R. (2005). Regional scale flood modelling using NEXRAD rainfall, GIS, and HEC-HMS/RAS: a case study for the San Antonio River Basin Summer 2002 storm event. Journal of Environmental Management, 75(4), 325-336.

3. Bryant, R. G., \& Rainey, M. P. (2002). Investigation of flood inundation on playas within the Zone of Chotts, using a time-series of AVHRR. Remote Sensing of Environment, 82(2-3), 360-375.

4. Sayama, T., Ozawa, G., Kawakami, T., Nabesaka, S., \&Fukami, K. (2012). Rainfall-runoff-inundation analysis of the 2010 Pakistan flood in the Kabul River basin. Hydrological Sciences Journal, 57(2), 298-312.

5. PDMA Khyber Pakhtunkhwa .(2015). Chitral Floods 2015: Recovery Needs Assessment and Action Plan. www.pdma.gov.pk

6. Azam, K., Yussof, R., \&Marwat, A. K. (2012). The role of coping capacities in disaster perspective: a case of Pakistan flash floods, 2010.

7. Shrestha, A. B., Chapagain, P. S., \&Thapa, R. (2011). Flash flood risk management: A training of trainers manual. International Centre for Integrated Mountain Development (ICIMOD).

8. Kundzewicz, Z. W., et al.. (2014). Flood risk and climate change: global and regional perspectives. Hydrological Sciences Journal, 59(1), 1-28.DOI: 10.1080/02626667.2013.857411.

9. Worni, R., Stoffel, M., Huggel, C., Volz, C., Casteller, A., \& Luckman, B. (2012). Analysis and dynamic modeling of a moraine failure and glacier lake outburst flood at Ventisquero Negro, Patagonian Andes (Argentina). Journal of Hydrology, 444, 134-145.

10. Campbell, J. G., \& Pradesh, H. (2005). Inventory of glaciers, glacial lakes and the identification of potential glacial lake outburst floods (GLOFs) affected by global warming in the mountains of India, Pakistan and China/Tibet Autonomous Region. International Centre for Integrated Mountain Development, www.apn-grc.org.

11. Rasul, G., Chaudhry, Q. Z., Mahmood, A., Hyder, K. W., \&Dahe, Q. (2011). Glaciers and glacial lakes under changing climate in Pakistan. Pakistan Journal of Meteorology 8(15).

12. WMO (World Meteorological Organization), (.2003).Our Future Climate (Publication WO-952). www.wmo.int.

13. Knebl, M. R., Yang, Z. L., Hutchison, K., \&Maidment, D. R. (2005). Regional scale flood modeling using NEXRAD rainfall, GIS, and HEC-HMS/RAS: a case study for the San Antonio River Basin Summer 2002 storm event. Journal of Environmental Management, 75(4), 325-336.

14. Sayama, T., Ozawa, G., Kawakami, T., Nabesaka, S., \&Fukami, K. (2012). Rainfall-runoff-inundation analysis of the 2010 Pakistan flood in the Kabul River basin. Hydrological Sciences Journal, 57(2), 298-312.

15. Bedient, P. B., Holder, A., Benavides, J. A., \& Vieux, B. E. (2003). Radar-based flood warning system applied to Tropical Storm Allison. Journal of Hydrologic Engineering, 8(6), 308-318.

16. Garrote, L., \& Bras, R. L. (1995). A distributed model for real-time flood forecasting using digital elevation models. Journal of Hydrology, 167(1-4), 279-306.

17. Garrote, L., \& Bras, R. L. (1995). A distributed model for real-time flood forecasting using digital elevation models. Journal of Hydrology, 167(1-4), 279-306.

18. Nehrkorn, T., Hoffman, R. N., Grassotti, C., \& Louis, J. F. (2003). Feature calibration and alignment to represent model forecast errors: Empirical regularization. Quarterly Journal of the Royal Meteorological Society, 129(587), 195-218.

19. Jayakrishnan, R., Srinivasan, R., \& Arnold, J. G. (2004). Comparison of raingauge and WSR-88D Stage III precipitation data over the Texas-Gulf basin. Journal of Hydrology, 292(1-4), 135-152.

20. Awadallah, A., and N. Awadallah, 2013: A novel approach for the joint use of rainfall monthly and daily ground station data with TRMM data to generate IDF estimates in a poorly gauged arid region. Open Journal of Modern Hydrology, 3, 1-7, doi:10.4236/ ojmh.2013.31001.

21. Li, X.-H., Zhang, Q. andXu, C.Y.,(2012): Suitability of the TRMM satellite rainfalls in driving a distributed hydrological model for water balance computations in Xinjiang catchment, Poyang lake basin. Journal of Hydrology, (426-427) 28-38, doi:10.1016/ j.jhydrol.2012.01.013.

22. Khan, S. I. et al. (2011)Hydroclimatology of Lake Victoria region using hydrologic model and satellite remote sensing data. Hydrology \& Earth System Sciiences, (15) 1, 107-117, doi:10.5194/ hess-15-107-2011. 
23. Wagner, S.,Kunstmann, H., Bardossy, A. , Conrad, C., \&Colditz, R.R. (2009) Water balance estimation of a poorly gauged catchment in West Africa using dynamically downscaled meteorological fields and remote sensing information. Physics and Chemistry of the Earth(34), 225-235, doi:10.1016/ j.pce.2008.04.002.

24. Asante, K. O., Arlan, G.O., S. Pervez, \& Rowland, J.(2008) A linear geospatial streamflow modeling system for data sparse environments.International Journal of River Basin Management, (6) 13, 233-241, doi:10.1080/15715124.2008.9635351.

25. Su, F., Hong, Y. \&Lettenmaier, D. (2008). Evaluation of TRMM multisatellite precipitation analysis (TMPA) and its utility in hydrologic prediction in the La Plata basin. Journal of Hydrometeorology (9) 622-640, doi:10.1175/2007JHM944.1.

26. Huffman, G. J. et al (2007). The TRMM multisatellite precipitation analysis (TMPA): Quasi-global, multiyear, combined-sensor precipitation estimates at fine scales. Journal of hydrometeorology, 8(1), 38-55.

27. Sawunyama, T.,\& Hughes, D. (2008) Application of satellite-derived rainfall estimates to extend water resource simulation modeling in South Africa. Water SA 34(1),1-9.

28. Yong B et al (2012) Assessment of evolving TRMM-based multisatellite real-time precipitation estimation methods and their impacts on hydrologic prediction in a high latitude basin. Journal of Geophysical Research,(117)doi:10.1029/2011JD017069

29. Hunukumbura, P.B., Weerakoon, S.B., Herath, S., (2008) Runoff modeling in the upper Kotmale Basin. In: N. Hennayake, N. Rekha,M, Nawfhal, R. Alagan, \&C. Daskon (Eds.), Traversing No Man's Land, Interdisciplinary Essays in Honor of Professor MaddumaBandara. (pp. 169-184). University of Peradeniya, Sri Lanka.

30. Feldman, A.D. (2000). Hydrologic Modeling System HEC-HMS, Technical Reference Manual. U.S. Army Corps of Engineers, Hydrologic Engineering Center, HEC, Davis, CA, USA.

31. Brunner, G. W. (1995). HEC-RAS River Analysis System. Hydraulic User's Manual. Version 1.0. Hydrologic Engineering Center Davis CA.

32. Khan, A. N. (2013). Analysis of 2010-flood causes, nature and magnitude in the Khyber Pakhtunkhwa, Pakistan. Natural hazards, 66(2), 887-904.

33. Khisroon, M., Farooqi, J., \& Masroor, R. (2012). Systematics, Ecology and Distribution of Caucasian Rock Agama, Paralaudakia Caucasia in District Chitral, Khyber Pakhtunkhwa Province, Pakistan. Putaj Sciences, 19.

34. Nawaz Khan, A. (2010). Climate change adaptation and disaster risk reduction in Pakistan. In R. Shaw, J.M. Pulhin, \& J.J. Pereira (Eds) Climate change adaptation and disaster risk reduction: An Asian perspective (pp. 197-215). Emerald Group Publishing Limited.

35. Rasul, G., Dahe, Q., \& Chaudhry, Q. Z. (2008). Global warming and melting glaciers along southern slopes of HKH ranges. Pakistan Journal of Meteorology, (5)9, 63 - 76.

36. Abdul Sattar Shakir1, Habib-ur-Rehman1, Saqib Ehsan Shakir. (2010). Climate change impact on river flows in Chitral watershed. Pakistan Journal of Engineering and Applied Sciences.

37. Bari, F., Yousafzai, A. M., \& Shah, S. Similarity in ichthyo diversity of two connected rivers in Pak-Afghan border: River Chitral and River Bashgal and their frequency of distribution.

38. Nigel J. R. Allan, Georg Buddruss. (1991 \& 2011).

EncyclopediaIranica.http://www.iranicaonline.org/articles/chitral-citral-river-valley-in-the-upper-indus-sy stem.

39. BOS-P\&DD and UNICEF- Peshawar (2014). District Profile - Chitral 2014http://kpbos.gov.pk/files/1432633137.pdf.

40. Ahrens, S.R., Maidment, D.R. (1999)Flood Forecasting for the Buffalo Bayou using CRWR-PrePro and HEC-HMS (CRWR Report 99-6). Center for Research in Water Resources, Austin, TX.

41. Anderson, M.L., Chen, Z.-Q., Kavvas, M.L., Feldman, A., (2002) Coupling HEC-HMS with atmospheric models for prediction of watershed runoff. Journal of Hydrologic Engineering (7)4, 312-318.

42. Knebl, M.R., Yanga, Z.L., Hutchisonb, K., Maidment, D.R., (2005) Regional scale flood modeling using NEXRAD rainfall, GIS, and HEC-HMS/RAS: a case study for the San Antonio River Basin Summer 2002 storm event. Journal of Environmental Management (75), 325-336.

43. Townsend, P.A., \&Walsh, S.J., (1998)Modeling floodplain inundation using an integrated GIS with radar and optical remote sensing. Geomorphology 21 (3-4), 295-312.

44. Cunderlik, J.M.,\&Simonovic, S.P. (2007). Hydrologic models for inverse climate change impact modeling. Paper presented at 18th Canadian Hydro-technical Conference, Winnipeg, Manitoba, August 2007. 
615
45. Hydrographs-Mark, S. A. C. O. Ann M Midje Banitt, PE, Hydraulic Engineer US Army Corps of Engineers, St. Paul, MN ann. m. banitt@ usace. army.mil.

46. Yang, J., Townsend, R. D., \&Daneshfar, B. (2006). Applying the HEC-RAS model and GIS techniques in river network floodplain delineation. Canadian Journal of Civil Engineering, 33(1), 19-28.

47. Cook, A., \&Merwade, V. (2009). Effect of topographic data, geometric configuration and modeling approach on flood inundation mapping. Journal of Hydrology, (377)1-2,, 131-142.

48. Ghimire, B., \& Deng, Z. Q. (2011). Event flow hydrograph-based method for shear velocity estimation. Journal of Hydraulic Research, 49(2), 272-275.

49. Ackerman, C. T., Jensen, M. R., \& Brunner, G. W. (2010). Geospatial capabilities of HEC-RAS for model development and mapping. In 2nd Joint Federal Interagency Conference, Las Vegas, NV.

50. Masood, M., \& Takeuchi, K. (2012). Assessment of flood hazard, vulnerability and risk of mid-eastern Dhaka using DEM and 1D hydrodynamic model. Natural Hazards, 61(2), 757-770.

51. Pappenberger, F., Beven, K., Horritt, M., \&Blazkova, S. (2005). Uncertainty in the calibration of effective roughness parameters in HEC-RAS using inundation and downstream level observations. Journal of Hydrology, 302(1-4), 46-69.

52. Freitag, B., Bolton, S., Westerlund, F., \& Clark, J. L. S., (2009). Floodplain management: a new approach for a new era $2^{\text {nd }}$ Ed. Washington, DC.: Island Press.

53. Khalid, S. ,Rehman, S. , Shah, S. , Naz, A. , Saeed, B. , Alam, S. , Ali, F. \& Gul, H. (2013) Hydro-meteorological characteristics of CRB at the peak of the Hindukush range. Natural Science (5)9, 987-992. doi: 10.4236/ns.2013.59120.

54. Merwade, V., Olivera, F., Arabi, M., \& Edleman, S. (2008). Uncertainty in flood inundation mapping: current issues and future directions. Journal of Hydrologic Engineering, 13(7), 608-620.

55. Pappenberger, F., Beven, K., Horritt, M., \& Blazkova, S. (2005). Uncertainty in the calibration of effective roughness parameters in HEC-RAS using inundation and downstream level observations. Journal of Hydrology, 302(1-4), 46-69.

56. Pappenberger, F., Matgen, P., Beven, K. J., Henry, J. B., \& Pfister, L. (2006). Influence of uncertain boundary conditions and model structure on flood inundation predictions. Advances in Water Resources, 29(10), 1430-1449.

57. Romanowicz, R., \& Beven, K. (1998). Dynamic real-time prediction of flood inundation probabilities. Hydrological Sciences Journal, 43(2), 181-196. 